\title{
Intercomparison of lidar, aircraft, and surface ozone measurements in the San Joaquin Valley during the California Baseline Ozone Transport Study (CABOTS)
}

\author{
Andrew O. Langford ${ }^{1}$, Raul J. Alvarez $\mathrm{II}^{1}$, Guillaume Kirgis ${ }^{1,2}$, Christoph J. Senff ${ }^{1,2}$, Dani Caputi ${ }^{3}$, \\ Stephen A. Conley ${ }^{4}$, Ian C. Faloona ${ }^{3}$, Laura T. Iraci ${ }^{5}$, Josette E. Marrero ${ }^{5, a}$, Mimi E. McNamara ${ }^{5,7, b}$, Ju-Mee Ryoo ${ }^{5, c}$, \\ and Emma L. Yates ${ }^{5,6}$ \\ ${ }^{1}$ Chemical Sciences Division, NOAA Earth System Research Laboratory, Boulder, CO 80305, USA \\ ${ }^{2}$ Cooperative Institute for Research in Environmental Sciences, University of Colorado, Boulder, CO 80309, USA \\ ${ }^{3}$ Department of Land, Air, and Water Resources, University of California, Davis, CA 95616, USA \\ ${ }^{4}$ Scientific Aviation, Inc., Boulder, CO 80301, USA \\ ${ }^{5}$ Atmospheric Science Branch, NASA Ames Research Center, Moffett Field, CA 94035, USA \\ ${ }^{6}$ Bay Area Environmental Research Institute, Petaluma, CA 94952, USA \\ ${ }^{7}$ Environmental Science and Policy Department, University of California, Davis, CA 95616, USA \\ ${ }^{a}$ now at: Sonoma Technology, Inc., Petaluma, CA 94954, USA \\ bnow at: Illingworth \& Rodkin, Inc., Petaluma, CA 94954, USA \\ ${ }^{c}$ now at: Science and Technology Corporation, Moffett Field, CA 94035, USA
}

Correspondence: Andrew O. Langford (andrew.o.langford@noaa.gov)

Received: 27 September 2018 - Discussion started: 23 October 2018

Revised: 16 February 2019 - Accepted: 6 March 2019 - Published: 25 March 2019

\begin{abstract}
The California Baseline Ozone Transport Study (CABOTS) was conducted in the late spring and summer of 2016 to investigate the influence of long-range transport and stratospheric intrusions on surface ozone $\left(\mathrm{O}_{3}\right)$ concentrations in California with emphasis on the San Joaquin Valley (SJV), one of two extreme ozone non-attainment areas in the US. One of the major objectives of CABOTS was to characterize the vertical distribution of $\mathrm{O}_{3}$ and aerosols above the SJV to aid in the identification of elevated transport layers and assess their surface impacts. To this end, the NOAA Earth System Research Laboratory (ESRL) deployed the Tunable Optical Profiler for Aerosol and oZone (TOPAZ) mobile lidar to the Visalia Municipal Airport $\left(36.315^{\circ} \mathrm{N}, 119.392^{\circ} \mathrm{E}\right)$ in the central SJV between 27 May and 7 August 2016. Here we compare the TOPAZ ozone retrievals with co-located in situ surface measurements and nearby regulatory monitors and also with airborne in situ measurements from the University of California at Davis-Scientific Aviation (SciAv) Mooney and NASA Alpha Jet Atmospheric eXperiment (AJAX) research aircraft. Our analysis shows that the lidar and aircraft
\end{abstract}

measurements agree, on average to within 5 ppbv, the sum of their stated uncertainties of 3 and 2 ppbv, respectively.

\section{Introduction}

The San Joaquin Valley (SJV) of California is one of only two "extreme" ozone $\left(\mathrm{O}_{3}\right)$ non-attainment areas remaining in the United States with a 2016 ozone design value, i.e., the metric used by the U.S. EPA to determine air quality compliance that is calculated as the 3-year average of the fourth highest measured maximum daily $8 \mathrm{~h}$ average mixing ratio (MDA8), which is more than 20 parts per billion by volume (ppbv) greater than the primary National Ambient Air Quality Standard (NAAQS) of 70 ppbv (https: //www3.epa.gov/airquality/greenbook/hdtc.html, last access: 18 March 2019). Such high $\mathrm{O}_{3}$ concentrations are harmful to human health (U.S. Environmental Protection Agency, 2014) and impair plant growth and productivity (Avnery et al., 2011a, b), adversely affecting both the USD 15 billion 
annual crop yield (https://quickstats.nass.usda.gov/results/ 9438C760-67AB-3AFB-B182-8484DB20A903, last access: 18 March 2019) in the SJV and the iconic forests of the nearby Sequoia National Park and Kings Canyon National Park (Panek et al., 2013).

The need to better understand the causes for the high surface $\mathrm{O}_{3}$ in the San Joaquin Valley has motivated several major air quality studies over the years including the San Joaquin Valley Air Quality Study (SJVAQS) in 1990 (Lagarias and Sylte, 1991), the Central California Ozone Study (CCOS) in 2000, (Reynolds et al., 2010) and the California Research at the Nexus of Air Quality and Climate Change (CalNex) field campaign in 2010 (Ryerson et al., 2013; Brune et al., 2016). More recently, this issue was addressed by the 2016 California Baseline Ozone Transport Study (CABOTS) organized and supported by the California Air Resources Board (CARB) (https://www.arb.ca. gov/research/cabots/cabots.htm, last access: 18 March 2019). CABOTS was designed to investigate the contributions of background $\mathrm{O}_{3}$ (Jaffe et al., 2018) and the influence of stratospheric intrusions (Lin et al., 2012a) and long-range transport from Asia (Lin et al., 2012b) on surface $\mathrm{O}_{3}$ concentrations in the SJV during late spring and summer. Characterization of the vertical distribution of $\mathrm{O}_{3}$ in the lower and middle free troposphere above the SJV and upwind regions with an accuracy of at least $10 \%$, the nominal accuracy of ECC ozonesondes in the troposphere (Smit et al., 2014), was a key objective of the campaign, and $\mathrm{O}_{3}$ profiles were measured using three different techniques (lidar, aircraft, and ozonesondes) in various parts of California. Integration of these datasets requires that these measurements be intercompared (Ancellet and Ravetta, 2005; Beekmann et al., 1995; Kempfer et al., 1994; Schäfer et al., 2002) and any differences among the various techniques understood and characterized. For pollution studies it is important that this validation includes the lowest $100 \mathrm{~m}$, which is inaccessible to most ozone lidars (Wang et al., 2017). In this paper, we compare $\mathrm{O}_{3}$ measurements from the NOAA Earth System Research Laboratory ESRL multi-angle Tunable Optical Profiler for Aerosol and oZone (TOPAZ) lidar with in situ measurements from nearby regulatory and research surface monitors, and also with instruments flown aboard the UC DavisScientific Aviation Mooney (Trousdell et al., 2016) and Alpha Jet research aircraft based at NASA's Ames Research Center (Hamill et al., 2016; Yates et al., 2015). These comparisons, together with those from the multi-lidar (including TOPAZ) and ozonesonde Southern California Ozone Observation Project (SCOOP) intercomparison conducted by the NASA-sponsored Tropospheric Ozone Lidar Network (TOLNet) immediately after CABOTS (Leblanc et al., 2018), provide this validation.

\section{California Baseline Ozone Transport Study (CABOTS)}

The CABOTS field campaign was conducted between midMay and mid-August of 2016. The primary measurements (see Fig. 1a) included electrochemical cell (ECC) ozonesondes (Johnson et al., 2002) launched daily from Bodega Bay $\left(38.319^{\circ} \mathrm{N}, 123.075^{\circ} \mathrm{E}, 12 \mathrm{~m}\right.$ above mean sea level, a.s.1.) (6 May-17 August) and Half Moon Bay $\left(37.505^{\circ} \mathrm{N}\right.$, $122.483^{\circ}$ E, 9 m a.s.l.) (15 July-17 August) by the San Jose State University (SJSU), in situ aircraft sampling of $\mathrm{O}_{3}$ and other compounds above central California by the University of California, Davis (UC Davis)-Scientific Aviation (Trousdell et al., 2016) and the NASA Alpha Jet Atmospheric eXperiment (AJAX) (Yates et al., 2015), and ozone and backscatter lidar measurements by the truck-based NOAA ESRL TOPAZ lidar system (Alvarez et al., 2011) at the Visalia Municipal Airport (VMA, 36.315 $\mathrm{N}, 119.392^{\circ} \mathrm{E}$, $88 \mathrm{~m}$ a.s.l.) (27 May-18 June and 18 July-7 August) (Fig. 2). Surface $\mathrm{O}_{3}$ measurements were also made at the ozonesonde and lidar sites and at the UC Davis monitoring station at the Chews Ridge Observatory $\left(36.306^{\circ} \mathrm{N}, 121.567^{\circ} \mathrm{E}\right.$, 1520 m a.s.l.) (Asher et al., 2018) in the Santa Lucia Mountains west of Visalia, as well as using the extensive networks of regulatory surface monitors maintained by the California Air Resources Board and the San Joaquin Valley Air Pollution Control District (SJVAPCD).

The Bodega Bay and Half Moon Bay sites were located on the coast to sample the Pacific inflow, and the VMA was chosen for the TOPAZ operations because of its central location in the SJV, the availability of the runway and airspace for low approaches and aircraft profiles, and the presence of the co-located SJVAPCD wind profiler and radio acoustic sounding system (RASS) (Bao et al., 2008). The TOPAZ truck was parked on the west side of the VMA between the airport runway and the heavily trafficked multilane CA-99 and adjacent San Joaquin Valley Railroad (SJVR) (Fig. 2). The VMA is located about $10 \mathrm{~km}$ west of downtown Visalia (pop. 130000) and lies about one-third $(60 \mathrm{~km})$ of the way from Fresno to Bakersfield (Fig. 1a, b). Visalia is located about $400 \mathrm{~km}$ from Bodega Bay and $300 \mathrm{~km}$ from Half Moon Bay, which limited the usefulness of comparisons between the lidar and ozonesondes.

\section{Ozone measurement platforms}

\subsection{NOAA-ESRL TOPAZ lidar}

The TOPAZ differential absorption lidar (DIAL) system was originally developed for the profiling of $\mathrm{O}_{3}$ and particulate backscatter in the planetary boundary layer and lower free troposphere from NOAA Twin Otter aircraft (Alvarez et al., 2011; Langford et al., 2010, 2011, 2012; Senff et al., 2010). The lidar was reconfigured for mobile ground-based mea- 

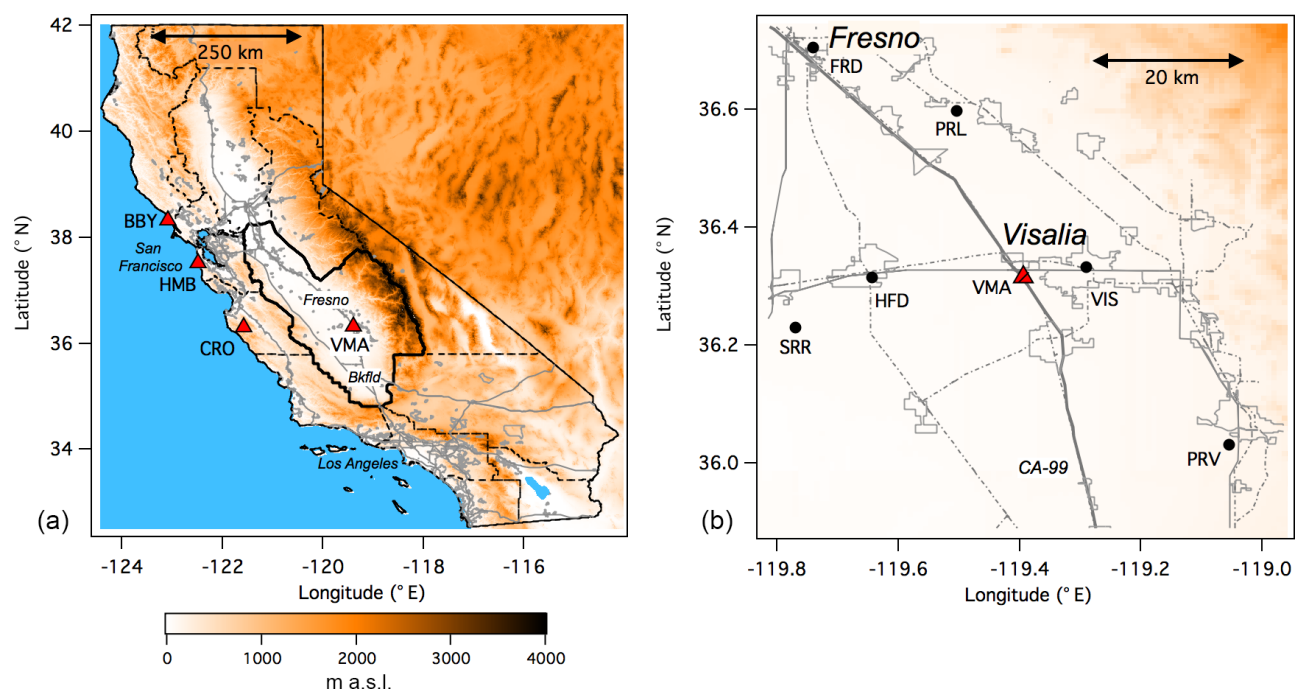

Figure 1. (a) Topographic map showing the air basins of California (dashed black lines); the San Joaquin Valley Air Basin (SJVAB) is outlined in heavy solid black. Interstate highways and urban areas are shown in gray. The filled red triangles show the CABOTS measurement sites at Bodega Bay (BBY), Half Moon Bay (HMB), Visalia Municipal Airport (VMA), and Chews Ridge Observatory (CRO). (b) The same as (a) but showing an enlarged view of the area surrounding the VMA. The solid and dotted-dashed gray lines represent the major highways and railroads, respectively, with the heavier solid line showing CA-99 (see text). The filled black squares show the six closest regulatory $\mathrm{O}_{3}$ monitors active during the CABOTS campaign: Visalia (VIS), Hanford (HFD), Santa Rosa Rancheria (SRR), Fresno-Drummond St. (FRD), Parlier (PRL), and Porterville (PRV). The elevation scale is the same as in (a).

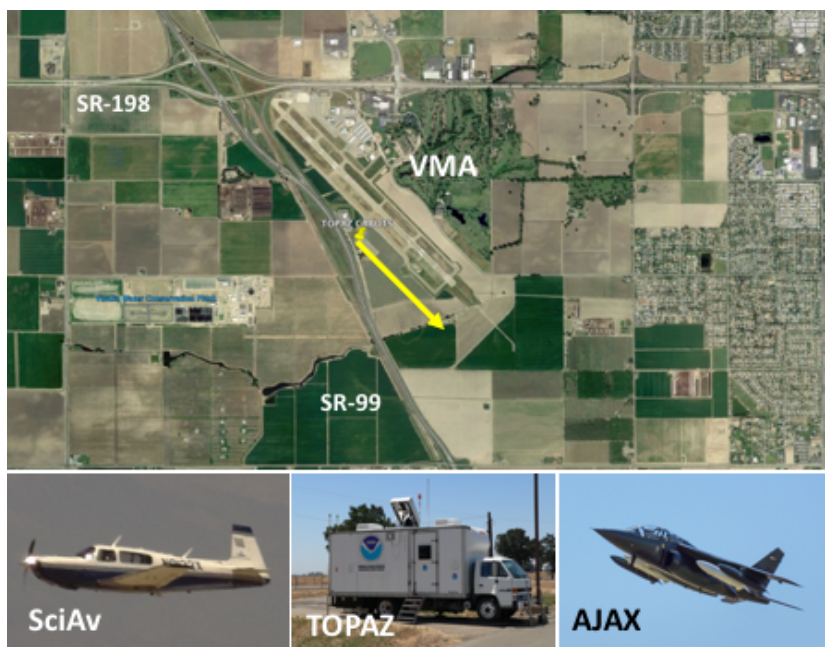

Figure 2. Aerial view of the Visalia Municipal Airport (VMA) showing the $1 \mathrm{~km}$ lidar slant path line of sight as a yellow arrow with the TOPAZ truck located at the base. The Scientific Aviation Mooney and AJAX Alpha Jet are shown flanking the NOAA ESRL TOPAZ truck below the Google Earth image. Mooney and TOPAZ photos by Andrew O. Langford. Alpha Jet photo by Wilfred von Dauster.

surements in 2012 and deployed in this configuration to several field campaigns including the 2013 Las Vegas Ozone Study (LVOS) (Langford et al., 2015) prior to CABOTS. The lidar is installed in the back of a medium box truck (see Fig. 2) equipped with a commercial UV absorption monitor for in situ $\mathrm{O}_{3}$ measurements (2B Technologies model 205) that samples air $5 \mathrm{~m}$ above the surface and an Airmar 150WX weather station to measure temperature, pressure, relative humidity, and wind speed and direction. The $2 \mathrm{~B}$ model 205 has been approved by the EPA as a federal equivalent method (FEM) for surface $\mathrm{O}_{3}$ monitoring and has a nominal $(1 \sigma)$ precision and accuracy that is the greater of $1 \mathrm{ppbv}$ or $2 \%$ for $10 \mathrm{~s}$ averages. Modified versions of the same instrument were flown on both the Scientific Aviation Mooney and NASA Alpha Jet. Comparisons between the NOAA 2B at the VMA and a mobile calibration source operated by CARB revealed a $3 \%$ low bias in the recorded $2 \mathrm{~B}$ measurements that has been corrected in the data used here.

The eye-safe TOPAZ lidar is built around a low pulse energy $(\sim 100 \mu \mathrm{J})$, high repetition rate $(1 \mathrm{kHz})$ quadrupled $\mathrm{Nd}$ :YLF pumped Ce:LiCAF laser that is retuned between each pulse to generate light at three different wavelengths from 286 to $294 \mathrm{~nm}$ with an effective repetition rate of $333 \mathrm{~Hz}$ for each wavelength (Alvarez et al., 2011). The laser pulses are transmitted and the lidar return signals collected by a coaxial transmitter and receiver equipped with a commercial (Licel) photomultiplier-based dual analog or photon counting system. This hybrid data acquisition system was installed in 2016 and replaced the original fast analog data acquisition system that was optimized for aircraft operations (Alvarez et al., 2011; Wang et al., 2017). This modification increased the maximum useful range to $\sim 6 \mathrm{~km}$ during the day and to more than $8 \mathrm{~km}$ at night, depending on the laser power, atmospheric extinction, and solar background light. 
The truck-mounted version of TOPAZ incorporates a large scannable turning mirror above the vertically pointing transmitter and receiver to allow profile measurements at different slant angles. These slant profiles can be combined to create vertical profiles that start much closer to the ground $(25-30 \mathrm{~m})$ than conventional vertically staring lidar systems (Proffitt and Langford, 1997). During CABOTS, the scanning mirror was moved sequentially between elevation angles of $90,20,6$, and $2^{\circ}$ with a $225 \mathrm{~s}$ averaging time at $90^{\circ}$ and $75 \mathrm{~s}$ averaging times at the other three angles. The cycle was repeated approximately every $8 \mathrm{~min}$ and the vertical projections combined to create a single vertical profile starting at $27.5 \pm 5 \mathrm{~m}$ above ground level (a.g.1.). This approach assumes a fair degree of horizontal homogeneity and the lidar slant paths were oriented parallel to the VMA runway $\left(135^{\circ}\right)$ over open farmland to avoid populated neighborhoods and minimize the effects of $\mathrm{NO}$ emissions from the often heavy traffic on CA-99 (see Fig. 2), which could locally titrate ozone and create strong horizontal concentration gradients near the surface.

The $\mathrm{O}_{3}$ profiles shown here were retrieved using two wavelengths ( $\sim 287$ and $294 \mathrm{~nm}$ ) with $30 \mathrm{~m}$ range gates and a smoothing filter that increased from $270 \mathrm{~m}$ wide at the minimum range $(815 \pm 15 \mathrm{~m})$ to $1400 \mathrm{~m}$ wide at the maximum range $(8 \mathrm{~km})$. The effective vertical resolution increased from $\sim 10 \mathrm{~m}$ near the surface to $\sim 150 \mathrm{~m}$ above $500 \mathrm{~m}$ a.g.l. and $900 \mathrm{~m}$ at $6 \mathrm{~km}$. Profiles of the backscatter from aerosols, smoke, and dust were retrieved with a constant $7.5 \mathrm{~m}$ resolution at $294 \mathrm{~nm}$. The ozone profiles were computed using the $\mathrm{O}_{3}$ absorption cross sections from Malicet et al. (1995) and an iterative technique to correct for differential aerosol backscatter and extinction that assumes a backscatter-toextinction ratio of 40 and fixed Ångström coefficients of 0 for backscatter and -0.5 for extinction (Alvarez et al., 2011). These values offer a good compromise for a wide variety of particulate types (Völger et al., 1996). The actual aerosol composition in the SJV was not measured during CABOTS, but measurements during the 2010 Carbonaceous Aerosols and Radiative Effects Study (CARES) typically found a mix of organics, sulfate, nitrate, ammonium, and soil dust in the northern part of the valley (Zaveri et al., 2012). Smoke from the Soberanes Fire near Big Sur dominated the aerosol mix in the SJV during the second intensive operating period (IOP). We varied the aerosol backscatter Ångström coefficient between -1 and 1 and the aerosol extinction Ångström coefficient between 0 and -1 for a "worst case scenario" of a thin smoke layer with very high aerosol backscatter embedded in an otherwise clean atmosphere to estimate the error in the ozone retrieval introduced by using these fixed parameters. The sharp aerosol gradients at the smoke layer edges tend to magnify errors in the ozone retrieval if the aerosol correction is not properly implemented. Temperature and pressure profiles interpolated from the $3 \mathrm{~h}$ National Centers for Environmental Prediction (NCEP) North American Regional Reanalysis (NARR) using the grid point closest to the TOPAZ lidar location were used to account for the temperature dependence of the $\mathrm{O}_{3}$ cross sections and to convert $\mathrm{O}_{3}$ number densities to mixing ratios. The total uncertainties in the $8 \mathrm{~min}$ ozone retrievals in the absence of strong aerosol gradients are estimated to increase from \pm 3 ppbv below $4 \mathrm{~km}$ to $\pm 10 \mathrm{ppbv}$ at the top of the profile. When strong backscatter gradients are present, the $\mathrm{O}_{3}$ uncertainty can potentially increase by another \pm 3 ppbv.

\subsection{UC Davis-Scientific Aviation Mooney}

The University of California at Davis and Scientific Aviation, Inc. (http://www.scientificaviation.com, last access: 18 March 2019) conducted a series of research flights above the SJV during the summer of 2016 using a Scientific Aviation single-engine Mooney TLS or Ovation aircraft as part of the CARB-supported Residual Layer Ozone Study (RLO) (https://www.arb.ca.gov/research/apr/ past/14-308.pdf, last access: 18 March 2019). Several of these flights overlapped with the TOPAZ operations during CABOTS, as did some of the 12 additional flights (EPA) funded by the U.S. EPA and the Bay Area Air Quality Management District (BAAQMD). The Mooney carried a 2B Technologies model $205 \mathrm{O}_{3}$ monitor, an EcoPhysics model CLD88 (NO) with a photolytic converter to measure NO and $\mathrm{NO}_{2}$, and a Picarro $2301 \mathrm{f}$ cavity ring-down spectrometer (CRDS) to measure $\mathrm{CO}_{2}, \mathrm{CH}_{4}$, and $\mathrm{H}_{2} \mathrm{O}$ (Trousdell et al., 2016). The $2 \mathrm{~B}$ model 205 was used with the minimum integration time of $2 \mathrm{~s}$, which corresponds to a mean distance of $150 \mathrm{~m}$ at the typical level flight speed (the data stream was sampled at $1 \mathrm{~s}$ intervals). As noted above, the $2 \mathrm{~B}$ has a nominal accuracy of $2 \%$ for concentrations above $50 \mathrm{ppbv}$ and a precision of $2 \%$ for concentrations above $50 \mathrm{ppbv}$ if $10 \mathrm{~s}$ averages are used. If the limiting noise is randomly distributed, this implies a precision of $5 \%$ for concentrations greater than $50 \mathrm{ppbv}$ and $2 \mathrm{~s}$ averages. Calibrations of the Scientific Aviation 2B using an external ozone source (2B, model 306) found the instrument to have offsets and slopes less than $1.5 \mathrm{ppb}$ and within $4 \%$ of unity, respectively.

\subsection{NASA Alpha Jet Atmospheric eXperiment (AJAX)}

The NASA Ames Alpha Jet Atmospheric eXperiment (AJAX) (Hamill et al., 2016) sampled $\mathrm{O}_{3}$ and other tropospheric constituents above California during CABOTS using a two-person jet based at Moffett Field, CA (MF, $37.415^{\circ} \mathrm{N}$, $\left.122.050^{\circ} \mathrm{E}\right)$. The Alpha Jet carried an external wing pod with a modified commercial UV absorption monitor (2B Technologies Inc., model 205) to measure $\mathrm{O}_{3}$ (Ryoo et al., 2017; Yates et al., 2013, 2015) and a (Picarro model $2301 \mathrm{~m}$ ) cavity ringdown analyzer to measure $\mathrm{CO}_{2}, \mathrm{CH}_{4}$, and $\mathrm{H}_{2} \mathrm{O}$ (Tanaka et al., 2016). A second wing pod carried a nonresonant laserinduced fluorescence instrument to measure formaldehyde $\left(\mathrm{CH}_{2} \mathrm{O}\right)$ (St. Clair et al., 2017). The pod mounting kept the residence times of the sample inlets to less than $2 \mathrm{~s}$. The air- 
craft is also equipped with GPS and inertial navigation systems to provide altitude and position information, and the NASA Ames-developed meteorological measurement systems to provide highly accurate pressure, temperature, and 3-D wind data. The $2 \mathrm{~B} \mathrm{O}_{3}$ data, recorded every $2 \mathrm{~s}$, are averaged over $10 \mathrm{~s}$ to increase the signal-to-noise ratio. Ozone calibrations were performed before or after each flight using an external ozone source (2B Technologies Inc., model 306 referenced to the NIST scale, certified annually). Raw flight $\mathrm{O}_{3}$ data were corrected using the linearity correction factor and zero-offset from the calibration closest in time to the flight. Overall accuracy of the $\mathrm{O}_{3}$ instrument is determined to be 3 ppbv or better at $10 \mathrm{~s}$ resolution, with uncertainty improving at lower altitudes, as determined from pressure chamber tests; see Yates et al. (2013) for a more detailed error analysis.

\section{Results and comparisons}

The TOPAZ measurements were conducted over two 3-week intensive operating periods (IOPs) in the late spring (27 May to 18 June) and summer (18 July to 7 August) of 2016. A total of $440 \mathrm{~h}$ of lidar data was recorded during the first (1654 profiles over 22 days) and second (1686 profiles over 21 days) IOPs with an average of more than $10 \mathrm{~h}$ of nearly continuous measurements per day. The skies above Visalia were mostly cloud free during the study, with only a few profiles truncated by high clouds during IOP1. However, during IOP2 the SJV was fumigated by smoke from the Soberanes Fire that started on 22 July about $200 \mathrm{~km}$ west of Visalia near Big Sur.

\subsection{Comparisons between lidar and surface measurements}

The NOAA 2B ozone monitor operated continuously at the VMA throughout the TOPAZ deployment, with the system response checked during each IOP by an external mobile calibration source operated by CARB. These calibration checks revealed a $3 \%$ low bias in the NOAA $2 \mathrm{~B}$ instrument that has been corrected in the data shown here. Figure 3 plots time series (Pacific daylight time, PDT) of the 1 min averaged in situ surface mixing ratios (gray dots) measured $5 \mathrm{~m}$ above the ground from each IOP together with the TOPAZ mixing ratios retrieved from a height of $27.5 \pm 5 \mathrm{~m}$ (black line) and a range of $815 \pm 15 \mathrm{~m}$ along the slant path above the agricultural fields to the southeast (see Fig. 2). Figure 4a is an enlarged view of the VMA surface measurements (gray line) from 9 to 13 June together with the mixing ratios from the $27.5 \mathrm{~m}$ TOPAZ measurements (filled black circles). Also plotted are the $1 \mathrm{~h}$ average ozone mixing ratios measured $6.7 \mathrm{~m}$ a.g.l. by the CARB regulatory Teledyne API 400 monitor located on N. Church Street in Visalia (102 m a.s.l.) about $10 \mathrm{~km}$ to the east of VMA (solid black line) and measured $5 \mathrm{~m}$ a.g.l. by the SJVAPCD Teledyne API 400 monitor in
Hanford ( $82 \mathrm{~m}$ a.s.1.) about $22 \mathrm{~km}$ to the west of VMA (dotted black line). The four sets of measurements agreed fairly well during the day but diverged markedly at night and in the early morning when $\mathrm{O}_{3}$ was removed by surface deposition and titration by $\mathrm{NO}_{x}$ within the surface layer. The losses were greatest at the VMA monitor which was located in the TOPAZ truck next to the heavily trafficked CA-99 and SJVR railroad line. Titration by NO was undoubtedly much greater here, but there were no $\mathrm{NO}_{x}$ measurements available to confirm this hypothesis. Much smaller losses were measured by the rural Hanford monitor and intermediate losses were measured by the Visalia monitor, which is located on a downtown rooftop. A scatterplot of all of the coincident TOPAZ and in situ measurements from CABOTS (Fig. 4b, filled gray circles) shows that the in situ concentrations measured at VMA were often much smaller than the concentrations measured $815 \pm 15 \mathrm{~m}$ away by the lidar, and even titrated to zero under some conditions. The data converge (filled black circles) when the comparison is restricted to conditions when the two measurements are expected to sample a common airmass; i.e., during the day after the nocturnal inversion has dissipated (09:00 to 18:30 PDT) and the winds were southeasterly $\left(125\right.$ to $\left.145^{\circ}\right)$ and greater than $2.5 \mathrm{~m} \mathrm{~s}^{-1}$. The results of orthogonal distance regression (ODR) fits of these data are shown both in the figure and in Table 1. We use ODR fits that assume that both variables can have uncertainties, for our analyses instead of simple linear regressions, which assume that all of the uncertainties lie in the dependent variable. Fits of the filtered data give a slope of $1.00 \pm 0.03$ and an intercept of $-2.6 \pm 1.5 \mathrm{ppbv}$ where the errors represent the $95 \%$ confidence limits of the ODR fits.

Figure 5 compares the $27.5 \mathrm{~m}$ TOPAZ $\mathrm{O}_{3}$ measurements to the regulatory $\mathrm{O}_{3}$ surface measurements from the monitors at Visalia $(8.5 \mathrm{~km})$ and Hanford $(24 \mathrm{~km})$ described above, and from the more distant SJVAPCD monitors at Parlier $(34 \mathrm{~km})$ and Porterville $(43 \mathrm{~km})$. The TOPAZ mixing ratios were slightly higher than those at Visalia and Hanford but lower than those at Parlier and Porterville, which are closer to the Sierra foothills and measure some of the highest $\mathrm{O}_{3}$ concentrations found in the SJVAB. The degree of correlation decreased with distance as expected, yet remained quite good more than $40 \mathrm{~km}$ from the VMA at Porterville. This suggests that the $\mathrm{O}_{3}$ measurements acquired at the VMA during CABOTS can be considered representative of the central San Joaquin Valley.

\subsection{Comparisons between lidar and aircraft measurements}

Comparisons between the ground-based lidar and aircraft measurements are subject to much larger uncertainties arising from spatial and temporal sampling differences compared with the comparison with nearby surface monitors. During CABOTS, the fixed wing aircraft conducted both low approaches above the VMA runway (see Fig. 2) and spiral 

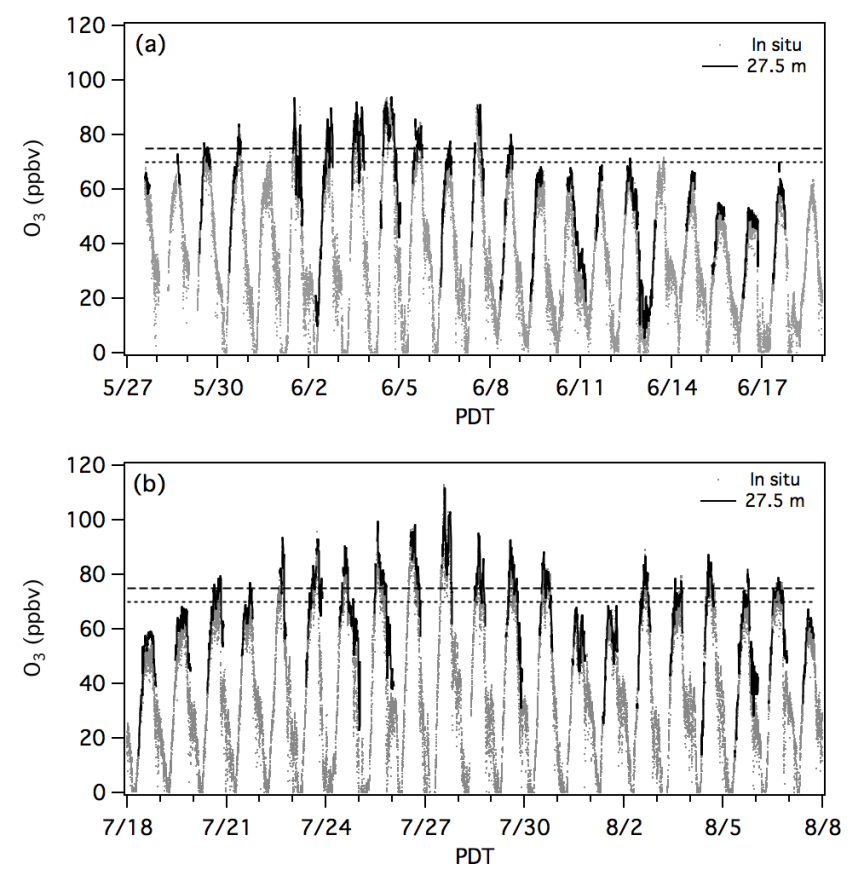

Figure 3. Time series plots (local Pacific daylight time, PDT) of the $\mathrm{O}_{3}$ concentrations retrieved $815 \pm 15 \mathrm{~m}$ downrange and $27.5 \mathrm{~m}$ above the surface by TOPAZ (black line) with the measurements from the in situ $2 \mathrm{~B}$ monitor sampling $5 \mathrm{~m}$ a.g.l. at the TOPAZ location (gray dots) during the first (a) and second (b) IOPs. The dashed and dotted lines show the 2008 (75 ppbv) and 2015 (70 ppbv) $\mathrm{O}_{3}$ NAAQS, respectively.

profiles around the airport but never directly sampled the vertical column probed by the lidar. The comparisons were also conducted as brief elements of multi-hour sampling flights with other objectives, and time constraints and air traffic considerations sometimes contributed to the spatial and temporal mismatches. The piston-engine Mooney took about $25 \mathrm{~min}$ to execute an ascending profile from the surface to $3 \mathrm{~km}$, while the Alpha Jet took about $9 \mathrm{~min}$ (similar to the $8 \mathrm{~min}$ TOPAZ integration time) to conduct a descending profile from $3 \mathrm{~km}$ to the surface. Spatial mismatches were also created by the vertically smoothing of the DIAL retrieval, which can both smooth and displace sharp vertical concentration gradients seen by the aircraft. Similar considerations apply to comparisons between lidars and ozonesondes since balloons have a finite rise time and can be carried many kilometers downwind from the launch site (Leblanc et al., 2018). Despite these caveats, we show that the lidar and aircraft measurements usually agreed to within $\pm 10 \%$, the nominal accuracy of ECC ozonesondes in the troposphere (Smit et al., 2014), which is the generally accepted reference standard for ozone profile measurements.
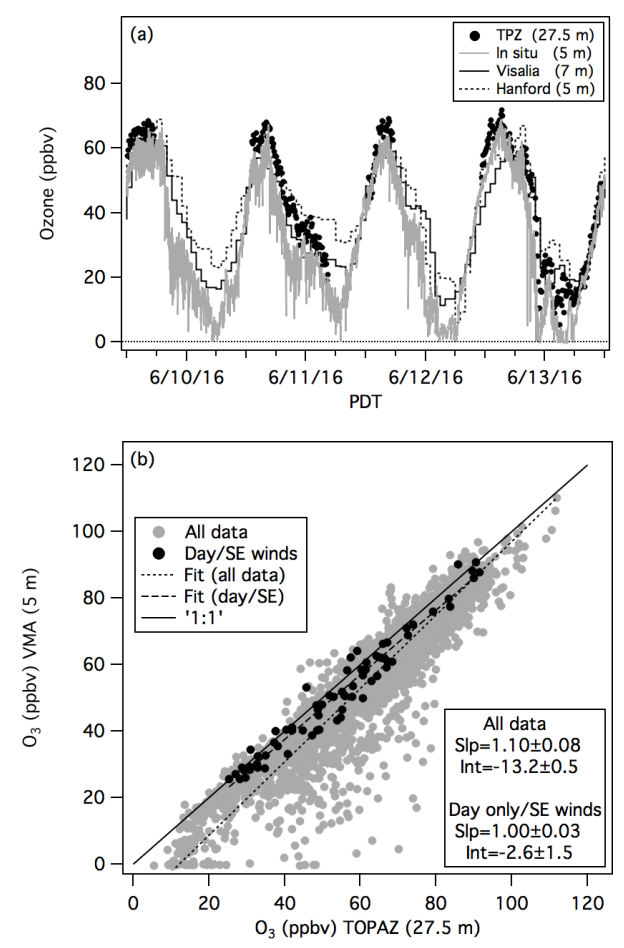

Figure 4. (a) A 4-day time series (9-13 June) showing the $\mathrm{O}_{3}$ concentrations in air sampled $5 \mathrm{~m}$ a.g.l. above the TOPAZ truck at the VMA (gray line) and the $\mathrm{O}_{3}$ mixing ratios at a height of $27.5 \pm 5 \mathrm{~m}$ and distance of $815 \pm 15 \mathrm{~m}$ retrieved from the TOPAZ measurements (filled black circles). The solid black and dotted staircase lines show the $1 \mathrm{~h}$ measurements from the Visalia and Hanford regulatory monitors. (b) Scatterplot comparing the $27.5 \mathrm{~m}$ TOPAZ measurements to the interpolated $5 \mathrm{~m}$ in situ measurements. The filled gray circles (with dotted ODR fit) show the entire CABOTS dataset from Fig. 3, and the filled black circles (with dashed ODR fit) show only those measurements made during the day (09:00 to 18:30 PDT) when the winds were southeasterly $\left(125\right.$ to $\left.145^{\circ}\right)$ and greater than $2.5 \mathrm{~m} \mathrm{~s}^{-1}$. The solid line shows the $1: 1$ correspondence.

\subsubsection{UC Davis-Scientific Aviation Mooney}

The RLO flights were executed as a series of 2-3-day deployments with as many as four flights per day lasting 2 to $3 \mathrm{~h}$ each between Fresno and Bakersfield. Two of these deployments, RLO2 (2-4 June) and RLO4 (24-26 July), overlapped with the first and second TOPAZ IOPs, respectively, and included low approaches at VMA on most of the flights with spiral profiles near VMA on several. Both deployments occurred as warm temperatures $\left(>40^{\circ} \mathrm{C}\right)$ and weak anticyclonic winds associated with synoptic high-pressure systems resulted in the buildup of surface ozone across the South Coast Air Basin and San Joaquin Valley Air Basin. The highest measured MDA8 $\mathrm{O}_{3}$ in the SJVAB during the first IOP was recorded on 4 June at Clovis (91 ppbv), which lies about $65 \mathrm{~km}$ northwest of VMA (see Fig. 1b). The highest reported MDA8 $\mathrm{O}_{3}$ during the second IOP (and the year) was recorded on 27 July at Parlier (101 ppbv), which lies midway between 

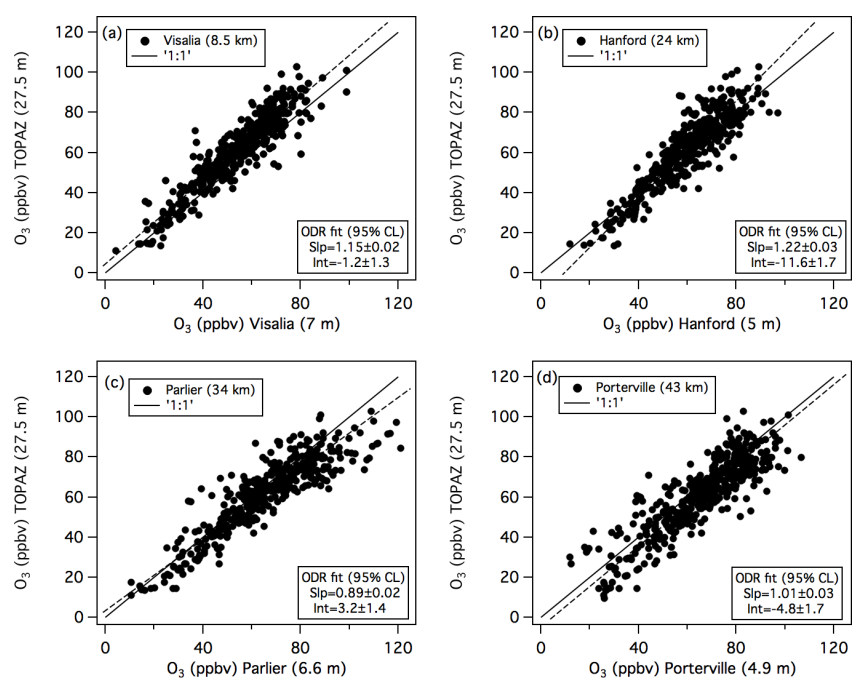

Figure 5. Scatterplots with ODR fits comparing the 27.5 m TOPAZ measurements with the $1 \mathrm{~h}$ measurements from the regulatory monitors at (a) Visalia-N. Church Street, (b) Hanford, (c) Parlier, and (d) Porterville. The measurements in the upper box and $x$ axis label refer to the distance from the VMA and sampling height above ground, respectively. The Visalia monitor is operated by the California Air Resources Board. The remaining three are operated by CARB and the SJVAPCD. The TOPAZ measurements are interpolated to the $1 \mathrm{~h}$ time base of the regulatory measurements for the comparison.

Clovis and the VMA. The monitors at Visalia and Hanford reported MDA8 concentrations of 72 and $88 \mathrm{ppbv}$, respectively, on 4 June, and 83 and 85 ppbv on 27 July. Figure 3 shows that the highest $\mathrm{O}_{3}$ mixing ratios measured by the VMA surface monitor and TOPAZ (27.5 m a.g.l.) were also recorded on these 2 days.

The flight tracks from all of the Mooney sorties during the RLO2 and RLO4 deployments are plotted in Fig. 6a. FLT29 (RLO4) was a transit flight from the Scientific Aviation home base near Sacramento to Fresno. The remaining RLO flights were between Fresno and Bakersfield as noted above. The two EPA deployments (27-29 July and 4-6 August) were of longer duration than the RLO flights with morning and afternoon sorties that placed more emphasis on cross-valley measurements and transects to the coast (Fig. 6b) including profiles above the South Bay (EPA1) and Chews Ridge (EPA2). The afternoon flights during both series included legs to Visalia.

Figure 7 shows the sections of the RLO and EPA flight tracks that passed within $5 \mathrm{~km}$ of TOPAZ (dashed black circles). Most of these flights included low $(<10 \mathrm{~m})$ passes along the VMA runway that approached within $\sim 350 \mathrm{~m}$ horizontally of the TOPAZ truck and within $1000 \mathrm{~m}$ of the center of the $27.5 \mathrm{~m}$ a.g.1. TOPAZ slant path measurements (see Fig. 2). Figure $8 \mathrm{a}-\mathrm{d}$ show time series of the $27.5 \mathrm{~m}$ TOPAZ and $5 \mathrm{~m}$ in situ measurements during all of the RLO and EPA low approaches together with the ozone measured by the aircraft between the surface and $25 \mathrm{~m}$ a.g.l. All of the aircraft measurements lie within $10 \%$ of the $\mathrm{O}_{3}$ retrieved by TOPAZ with the exception of the much higher values (>100 ppbv) measured by the Mooney around 14:00 PDT on 3 June (Fig. 8a; see below). The scatterplots in Fig. 8e and $f$ show that the aircraft also measured much higher concentrations than the in situ surface monitor during the night and early morning, in agreement with the lidar measurements in Fig. 4. The differences were smaller on 27 July than on 3 June, and also less pronounced than those in Fig. 4. Closer agreement between the aircraft and surface measurements might be expected since some of the aircraft measurements were made within $200 \mathrm{~m}$ of the lidar truck (see Fig. 2). The dark blue points show that the low bias in the surface measurements decreased during the day after the surface inversion had dissipated (there were too few measurements to effectively filter them by wind speed or direction). The mean ODR fit parameters based on the measurements from both RLO2 and RLO4 listed in Table 1 are very similar to those found for the lidar, which suggests that the filtered surface measurements still have low bias that could be either instrumental or sampling related.

Figure 9 compares the aircraft and lidar $\mathrm{O}_{3}$ measurements made during five of the ascending profiles conducted by the Mooney near the VMA. FLT19 was conducted in the early afternoon of 3 June and FLT33, FLT35, FLT36, and FLT37 were conducted over the $24 \mathrm{~h}$ period beginning just after local midnight on 25 July. The four consecutive TOPAZ profiles acquired during the time required for the Mooney to reach the top of each profile $(\sim 15-30 \mathrm{~min}$ at a climb rate of $\sim 2.2 \mathrm{~m} \mathrm{~s}^{-1}$ ) are plotted in each panel. The gray envelopes show the lidar mean profile $\pm 10 \%$. The differences between consecutive profiles reflect the combined effects of atmospheric variability and the precision of the lidar measurements.

Overall, the agreement between the TOPAZ and Mooney profiles in Fig. 9 is within $\pm 10 \%$, but there are some notable discrepancies. Most of these arise from the coarser vertical resolution of the lidar retrievals, which smooth out abrupt concentration changes such as those seen at the top of the boundary layer ( $\sim 0.8 \mathrm{~km}$ a.g.l.) in Fig. 9a and between 2 and $3 \mathrm{~km}$ in Fig. 9e where several narrower layers are smoothed into one broad layer in the lidar profile. Figure 9e also shows that the agreement between the lidar and aircraft measurements is better at low altitudes where the addition of the slant path measurements significantly improves the effective vertical resolution of the lidar. Fine-scale variability in $\mathrm{O}_{3}$ also contributes to some of the observed differences, particularly on 3 June when the aircraft-measured $\mathrm{O}_{3}$ concentrations varied by as much $25 \mathrm{ppbv}$ during the low approach over the VMA runway. This unusually large variability is also seen in the large and rapid changes in the lidar measurements near the top of the boundary layer (Fig. 9a) and challenges the assumptions about horizontal homogeneity used in the calculation of the TOPAZ vertical profiles near the surface. 

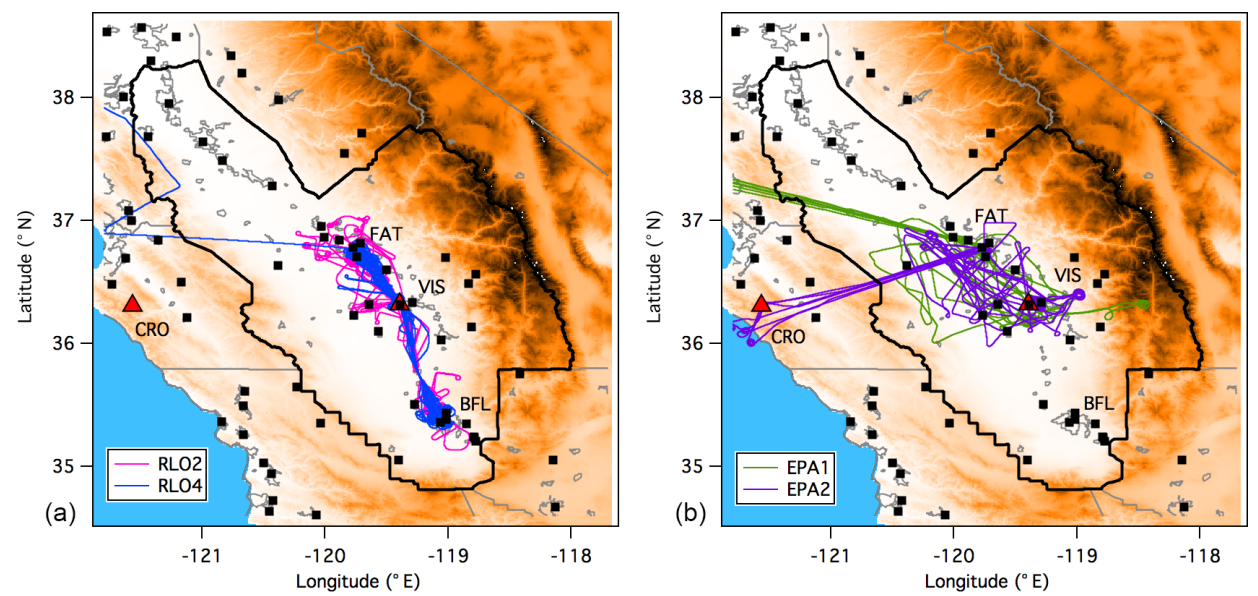

Figure 6. (a) Map of the San Joaquin Valley showing the RLO flight tracks coincident with the TOPAZ measurements (RLO2 and RLO4). The filled black squares show the regulatory surface monitors. The CABOTS sampling sites at CRO and VMA are marked by red triangles. The other abbreviations are the Fresno (FAT), Visalia (VIS), and Bakersfield (BFL) airport codes. Note that VMA and VIS refer to the same airport. (b) The same as (a) but with the EPA flight tracks (EPA1 and EPA2).
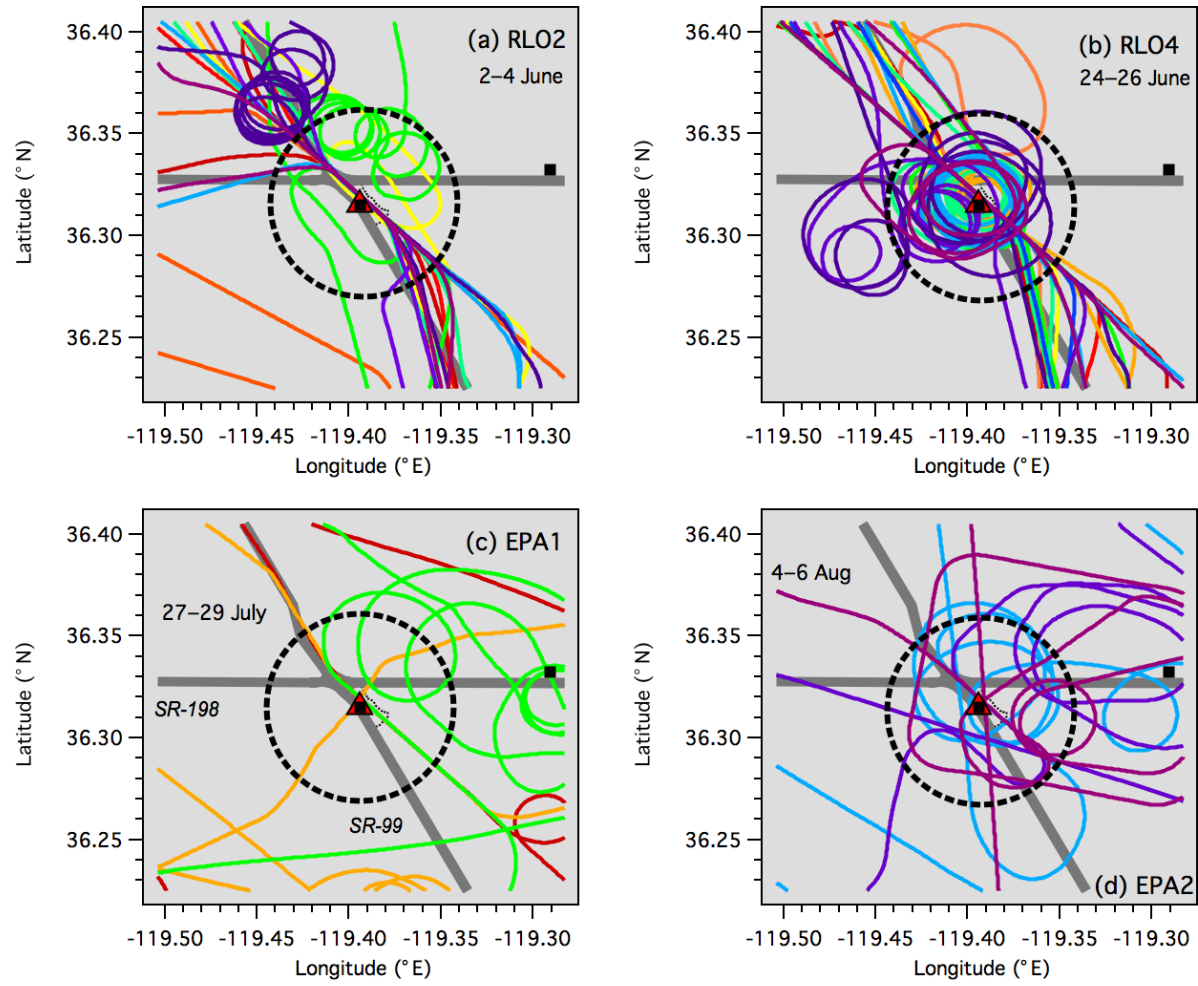

Figure 7. RLO and EPA flight tracks in the vicinity of TOPAZ. (a) RLO2 (2-4 June), (b) RLO4 (24-26 July), (c) EPA1 (27-29 July), and (d) EPA2 (4-6 August). Each color represents a different flight. The red triangle with a black square marks the location of TOPAZ at the VMA and the dashed black circles show the $5 \mathrm{~km}$ radius used for the profile comparisons. The lone black square represents the Visalia-N. Church St. $\mathrm{O}_{3}$ monitor.

The lidar profiles from 26 July (Fig. 9e) also show large profile-to-profile changes in the narrow high $\mathrm{O}_{3}$ layer lying just above the top of the nocturnal boundary layer $(\sim$ $0.3 \mathrm{~km}$ a.s.1.). The 25 and 26 July measurements (Fig. 9be) were made several days after the Soberanes Fire started and the low-altitude "layer" near $400 \mathrm{~m}$ in Fig. 9e is actually a short-lived puff of smoke and elevated $\mathrm{O}_{3}$ from the fire. This is more obvious in the expanded view of the profiles shown in Fig. 10a. Only two of the four lidar profiles from Fig. 9e are plotted: the first profile coinciding with the air- 

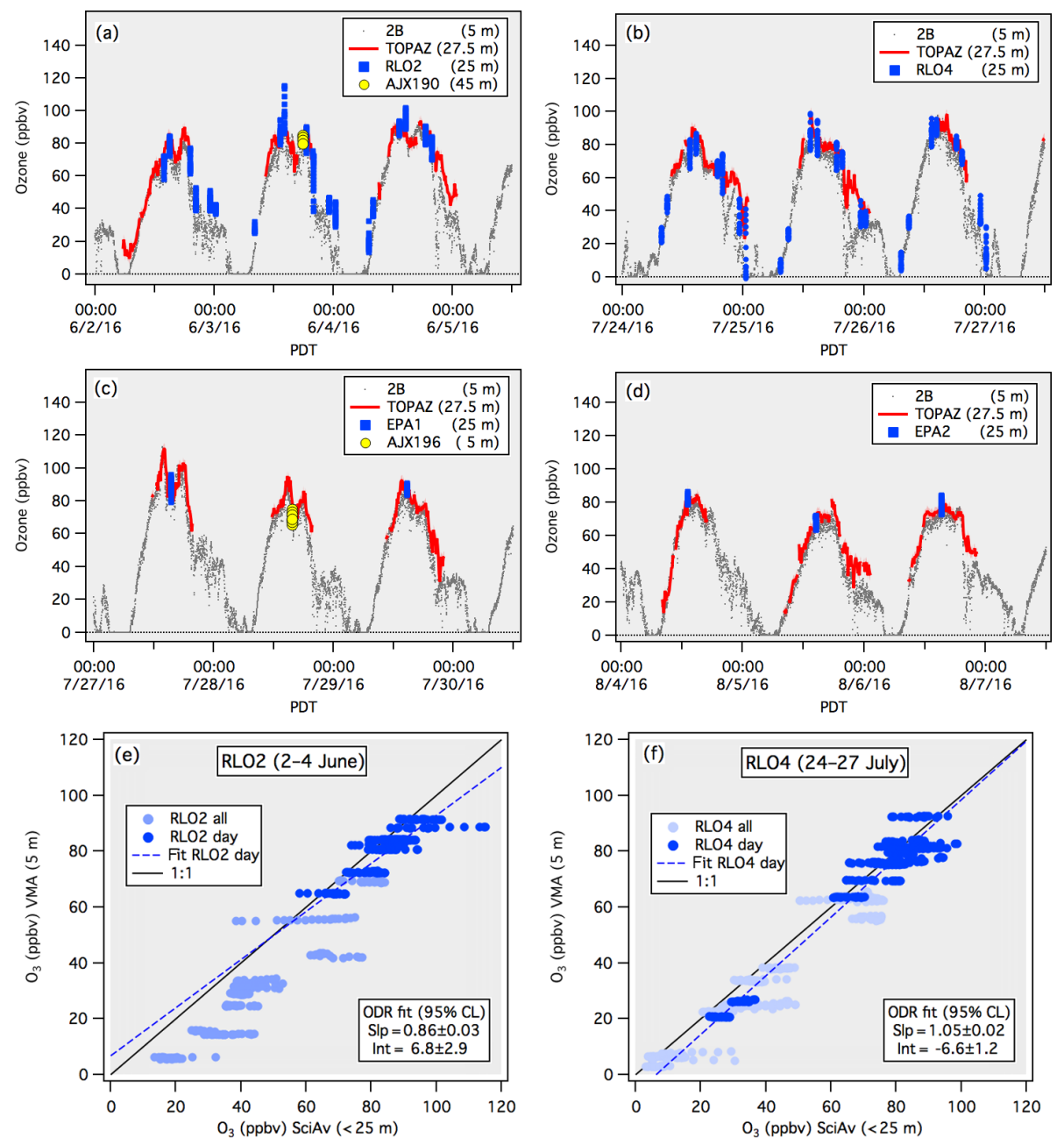

Figure 8. (a-d) Time series of the surface in situ $\mathrm{O}_{3}$ (gray dots) and $27.5 \mathrm{~m} \mathrm{TOPAZ} \mathrm{O}_{3}$ (red line) measured during the RLO and EPA low approaches on (a) 2-5 June, (b) 24-27 July, (c) 27-30 July, and (d) 4-7 August 2016. The red envelope shows the TOPAZ data \pm 3 ppbv, the nominal accuracy of the lidar retrievals. The blue squares represent the $1 \mathrm{~s}$ sampled ( $2 \mathrm{~s}$ recorded) Scientific Aviation measurements made between the surface and $25 \mathrm{~m}$ a.g.l. The filled yellow circles in (a) and (c) show $2 \mathrm{~s}$ measurements from AJAX low approaches (see text). Panels (e) and (f) show scatterplots of the in situ surface measurements and the Scientific Aviation data from the RLO flights in panels (a) and (b), respectively. The ODR fit parameters refer to the dark blue points which represent the measurements from daytime (08:30-18:30 PDT) flights.

craft measurements (solid trace, $\pm 10 \%$ ) and the profile acquired 16-24 min later when the puff had mostly disappeared (dashed trace). The corresponding lidar backscatter measurements are plotted in Fig. 10b, and Fig. 10c shows the $\mathrm{NO}_{2}$ and $\mathrm{H}_{2} \mathrm{O}$ profiles measured by the aircraft. The backscatter measurements show that the TOPAZ retrievals are unaffected by strong backscatter gradients, which can create second derivative-like inflection points in the DIAL $\mathrm{O}_{3}$ profiles (Kovalev and McElroy, 1994). The absence of a corresponding structure in the aircraft $\mathrm{NO}_{2}$ and $\mathrm{H}_{2} \mathrm{O}$ profiles confirms that the high $\mathrm{O}_{3}$ layer seen in the lidar and aircraft measurements was not an artifact caused by interferences from these species, which weakly absorb between 280 and $300 \mathrm{~nm}$ (Proffitt and Langford, 1997).

\subsubsection{NASA Alpha Jet Atmospheric eXperiment (AJAX)}

AJAX conducted four research flights over the SJV while TOPAZ was operational, with two additional flights (21 June and 7 July) between the two IOPs. The Alpha Jet executed descending spiral profiles from 4 to $5 \mathrm{~km}$ down to the surface that ended in low approaches on three of these flights: AJX190 on 3 June, AJX191 on 15 June, and AJX195 on 21 July. The aircraft also conducted a very low approach $(\sim 5 \mathrm{~m})$ at VMA on 28 July (AJX196) but did not execute a full profile. These low approach measurements are represented by the filled yellow circles in Fig. 8a and c. The first and last flights (AJX190 and AJX196) coincided with the 


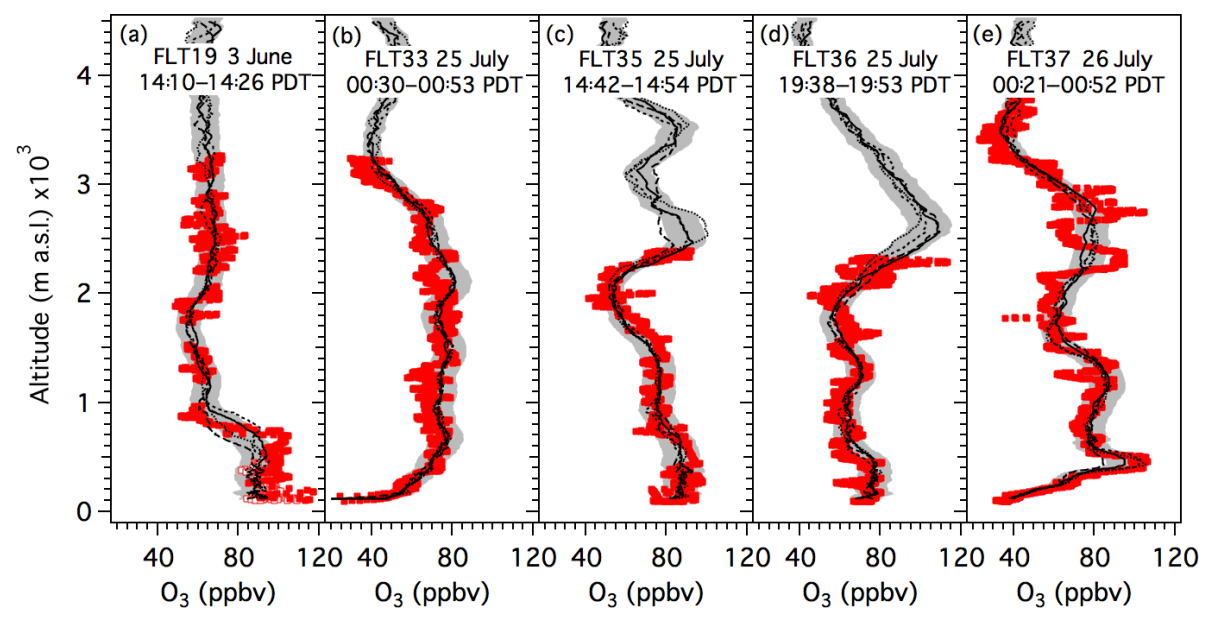

Figure 9. Profile plots comparing the TOPAZ (black lines) and Scientific Aviation (red squares) $\mathrm{O}_{3}$ measurements on (a) FLT19, 3 June; (b) FLT33, 25 July; (c) FLT35 25 July; (d) FLT36, 25 July; and (e) FLT37, 26 July. The dotted, short-dashed, solid, and long-dashed lines show the four consecutive 8 min lidar profiles acquired during the aircraft profiles. The gray envelopes show the mean lidar profile $\pm 10 \%$ as reference. Note the large variability near the surface and the sharp transition at $800 \mathrm{~m}$ in the 3 June aircraft measurements (see Fig. $3 \mathrm{a}$ ).

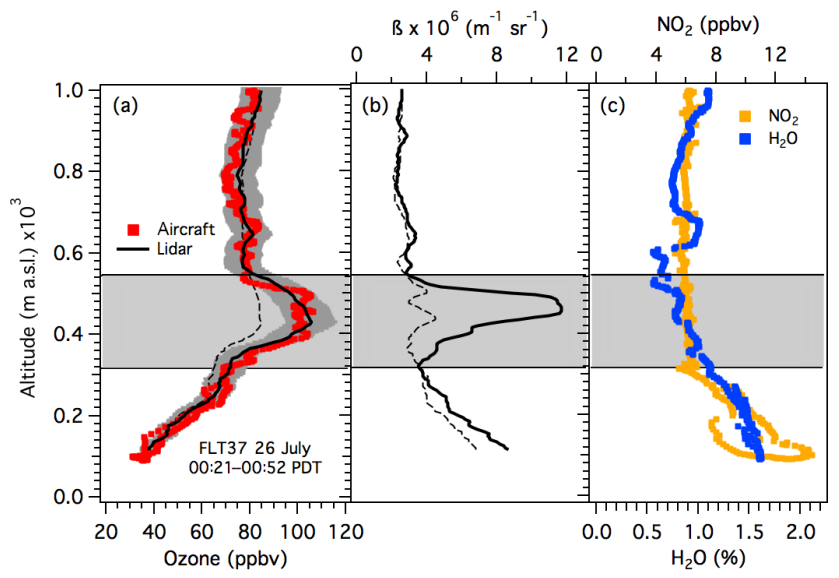

Figure 10. (a) Expanded view of the lidar and aircraft $\mathrm{O}_{3}$ profiles from Fig. 9e plotted with coincident (b) lidar backscatter and (c) aircraft $\mathrm{NO}_{2}$ and $\mathrm{H}_{2} \mathrm{O}$ profiles. The solid black profile ( $\pm 10 \%$ in gray) in (a) shows the lidar profile coinciding with the aircraft measurements below $1 \mathrm{~km}$; the dashed black line shows the profile measured 16-24 min later. This is also true for the backscatter profiles in (b). The horizontal gray band highlights the smoke puff from the Soberanes Fire.

high-ozone episodes mentioned earlier, and the third flight (AJX195) also occurred during a period of high pressure. The second flight (AJX191) was conducted as a deep closed low moved into the Pacific Northwest, however, bringing unseasonably cool temperatures $\left(26^{\circ} \mathrm{C}\right)$ and strong surface winds to the SJV. This cyclonic system advected a large Asian pollution plume across the valley in the middle troposphere, but surface ozone remained low with the peak MDA8 $\mathrm{O}_{3}$ concentration in the SJVAB only reaching 59 ppbv at the SequoiaKings Canyon monitor.
Figures 11 and 12 are similar to Figs. 6 and 7 but instead show the AJAX flight tracks. The first AJAX flight (AJX190) on 3 June during IOP1 overlapped with the UC Davis-Scientific Aviation RLO2 deployment. AJX191 took place about 2 weeks later in IOP1, and AJX195 occurred several days prior to the RLO4 deployment in IOP2. AJAX also executed profiles (not shown here) above and upwind of Chews Ridge on AJX190 and AJX191, near Bodega Bay on AJX191 and 195, and the Soberanes Fire plume on AJX196.

Figure 13 displays coincident AJAX and TOPAZ profiles in plots similar to those shown for the Mooney in Fig. 9 but with an extended vertical axis to reflect the higher range of these profiles. The points in Fig. 13 are sparser than those in Fig. 9 in part because of the $10 \mathrm{~s}$ averaging time, and in part because the Alpha Jet executed its descending profiles with an airspeed of about $110 \mathrm{~m} \mathrm{~s}^{-1}$ compared to about $60 \mathrm{~m} \mathrm{~s}^{-1}$ for the ascending Mooney profiles.

The agreement between the Alpha Jet and TOPAZ measurements is within $\pm 10 \%$ on all 3 days except for 3 June (Fig. 13a), when the measured aircraft and retrieved lidar concentrations differ by as much as $12 \mathrm{ppbv}(20 \%)$ at $2.5 \mathrm{~km}$ a.s.1. and $20 \mathrm{ppbv}(\sim 50 \%)$ at $5.2 \mathrm{~km}$ a.s.1. The disparities between the inbound and outbound measurements in Fig. 13a show that the Alpha Jet encountered strong horizontal gradients below $800 \mathrm{~m}$ in the boundary layer when it arrived at the VMA about $3 \mathrm{~h}$ after the Mooney found similar horizontal variability (see Figs. 8a and 9a). The Google Earth map and latitude-altitude and longitude-altitude plots in Fig. 14 better illustrate the extent of the horizontal variability in the boundary layer. These figures also show weaker horizontal gradients above $3 \mathrm{~km}$ where the disagreement between the lidar and aircraft is most pronounced. 
Table 1. Summary of the lidar, surface, and aircraft comparisons.

\begin{tabular}{llrrrr}
\hline A & B & Ratio $\pm 1 \sigma(\mathrm{A} / \mathrm{B})$ & Diff. $\pm 1 \sigma(\mathrm{A}-\mathrm{B})$ & Slope $^{*}$ (A vs. B) & Int.* (A vs. B) \\
\hline TOPAZ & VMA & $1.06 \pm 0.08$ & $2.9 \pm 3.7 \mathrm{ppbv}$ & $1.00 \pm 0.03$ & $-2.6 \pm 1.5 \mathrm{ppbv}$ \\
SciAv & VMA & $1.07 \pm 0.10$ & $5.0 \pm 5.0 \mathrm{ppbv}$ & $1.01 \pm 0.01$ & $-4.5 \pm 1.1 \mathrm{ppbv}$ \\
TOPAZ & SciAv & $1.01 \pm 0.04$ & $0.8 \pm 2.8 \mathrm{ppbv}$ & $1.00 \pm 0.13$ & $1.0 \pm 9.0 \mathrm{ppbv}$ \\
TOPAZ & AJAX & $1.08 \pm 0.06$ & $4.2 \pm 0.8 \mathrm{ppbv}$ & $1.07 \pm 0.13$ & $1.8 \pm 3.4 \mathrm{ppbv}$ \\
\hline
\end{tabular}

* From orthogonal distance regression (ODR) fits. Uncertainties are $95 \%$ confidence limits.

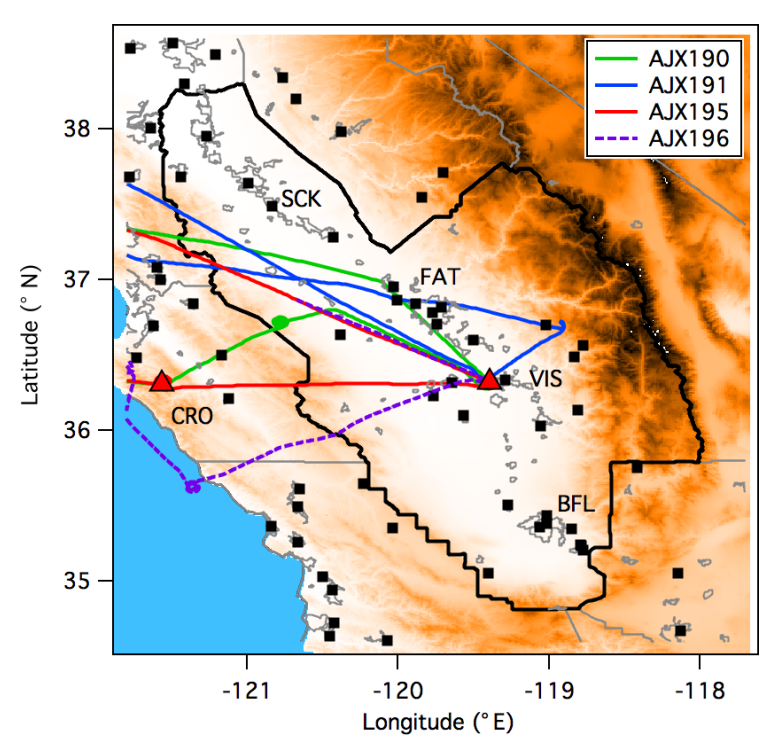

Figure 11. Map of the San Joaquin Valley showing the AJAX flight tracks on 3 June (AJX190), 15 June (AJX191), 21 July (AJX195), and 28 July (AJX196). The abbreviations and symbols are the same as in Fig. 6.

\section{Discussion}

The results of the different $\mathrm{O}_{3}$ comparisons are summarized in Table 1. As was noted above, comparisons between the lidar and aircraft profiles are subject to uncertainties arising from sampling differences introduced by the intrinsic vertical smoothing of the lidar retrievals and horizontal displacements between the aircraft and lidar. The potential impact of horizontal displacements on the comparisons when the $\mathrm{O}_{3}$ spatial variability is large is illustrated by Fig. 14, and a good example of the differences created by the lidar smoothing is seen near the top of the boundary layer around $0.8 \mathrm{~km}$ in Fig. 9a. These uncertainties can be reduced by averaging the measurements to be compared over larger volumes. Figure 15 compares the lidar and aircraft measurements from the profiles plotted in Figs. 9 and 13, and from several other RLO and EPA flights not shown, with each individual profile averaged over $1 \mathrm{~km}$ segments ( 0 to $1 \mathrm{~km}, 1$ to $2 \mathrm{~km}$, etc.). This averaging decreases the influence of $\mathrm{O}_{3}$ spatial variability and also reduces the statistical uncertainties in both the

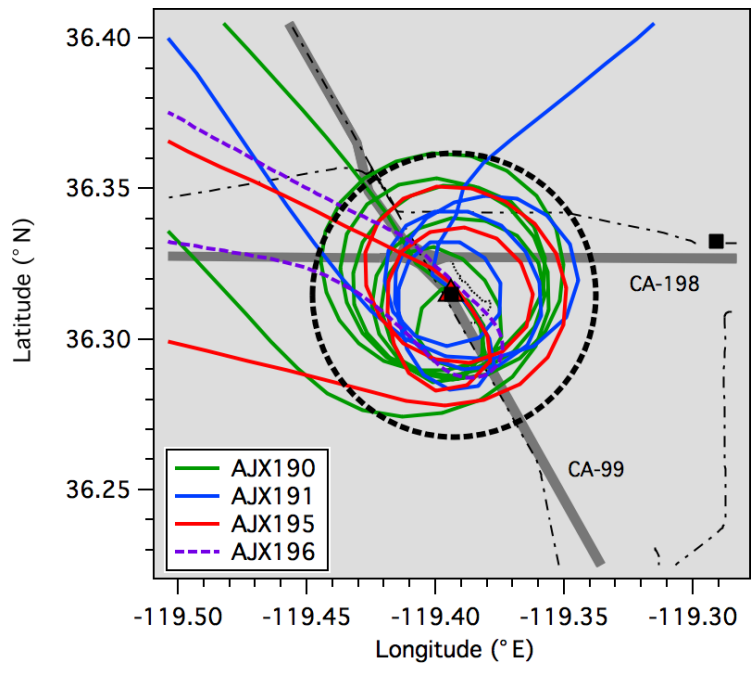

Figure 12. AJAX flight tracks in the vicinity of the VMA (red triangle with a black square). The lone black square represents the Visalia-N. Church St. $\mathrm{O}_{3}$ monitor and the dashed black circle marks the $5 \mathrm{~km}$ radius window used for the profile comparisons. The heavy gray lines show the major highways and the black dotted-dashed lines the railroads.

lidar retrievals and aircraft measurements, with the effective temporal averaging of the AJAX and SciAv measurements increasing to about 2 and $4 \mathrm{~min}$, respectively. Each point in the scatterplots of Fig. 15a and b represents the mean mixing ratio from one of these $1 \mathrm{~km}$ segments, with the error bars showing the standard deviation of the mean. The intercepts and slopes derived from orthogonal distance regressions of both datasets overlap with zero and unity, respectively, within the $95 \%$ confidence limits of the ODR fits. The lower panels (Fig. 15c and d) plot the same data as differences which show that the TOPAZ and SciAv measurements (Fig. 15c) agree to within $1 \mathrm{ppbv}$ on average, and the TOPAZ and AJAX measurements (Fig. 15d) to within 4.2 ppbv. Neither plot shows evidence of a systematic altitude dependence in the differences.

Both lidar-aircraft comparisons are limited by the small number of common measurements with only three profiles available for the AJAX comparisons. The SciAv comparisons include data from seven flights, but only the five profiles shown in Fig. 9 extend above $2 \mathrm{~km}$ and only three of those 

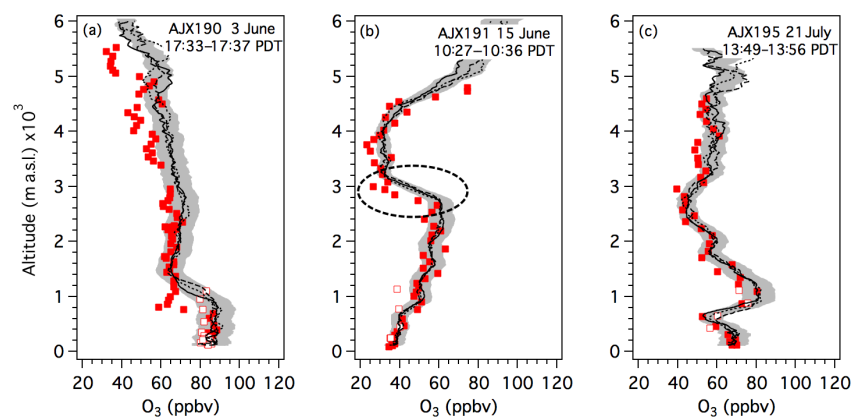

Figure 13. Profile plots comparing the TOPAZ (black lines) and $10 \mathrm{~s}$ AJAX (red squares) measurements on (a) AJX190, 3 June; (b) AJX191, 15 June; and (c) AJX195, 21 July. The closed squares correspond to the Alpha Jet descent and the open squares the subsequent climb out. Note the differences between these measurements. The dotted, dashed, and solid lines show the order of the three $8 \mathrm{~min}$ lidar profiles that bracket the AJAX profile. The gray envelopes show the mean lidar profile $\pm 10 \%$ as reference. The significance of the dashed oval in (b) is discussed in the text.
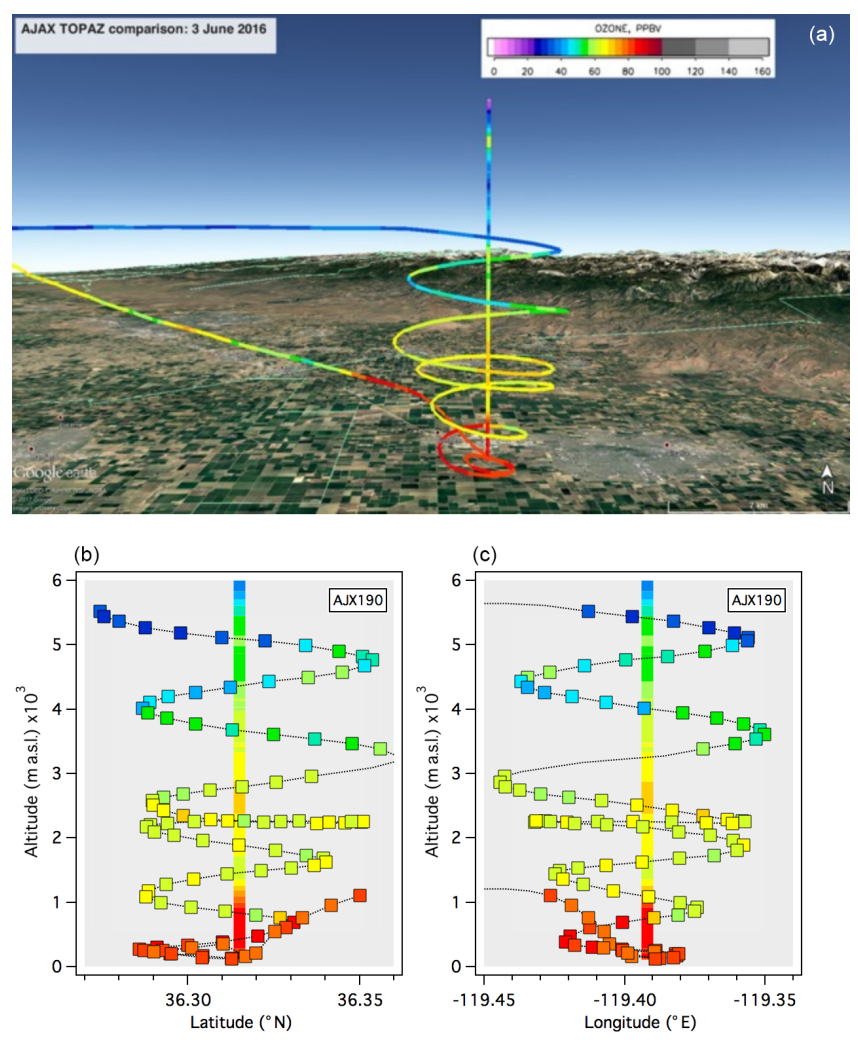

Figure 14. (a) Google Earth image of the TOPAZ and AJAX profiles from 3 June 2016 showing the spatial variations across the $\sim 8 \mathrm{~km}$ diameter spiral profile by the Alpha Jet during its descent and climb out over the VMA. (b, c) AJAX and TOPAZ profiles from Fig. 13a plotted as a function of latitude (b) and longitude (c). Both plots are $10 \mathrm{~km}$ wide. Note the strong horizontal gradients below $1.2 \mathrm{~km}$.
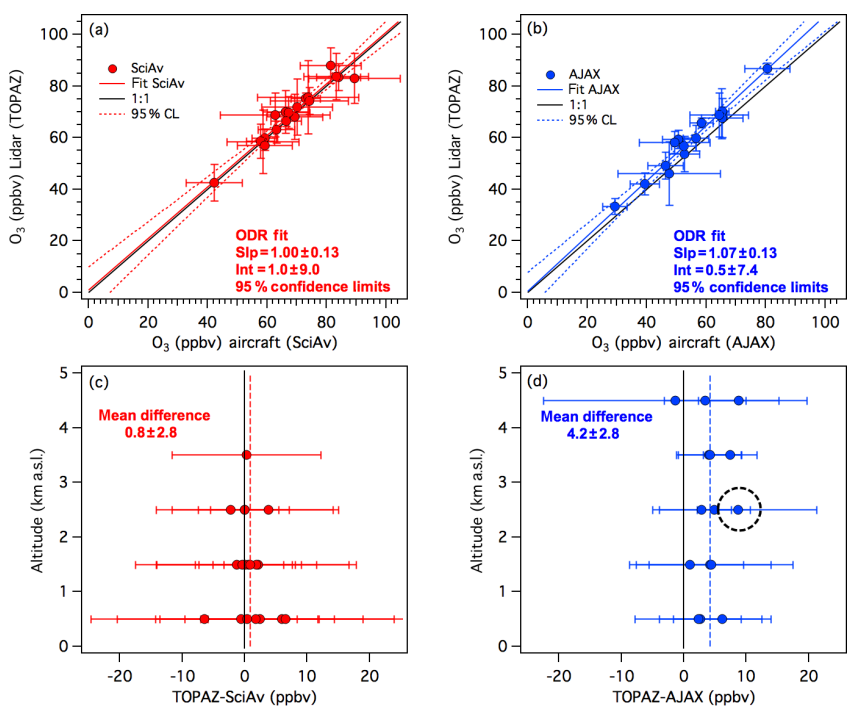

Figure 15. (a, b) Scatterplots comparing the TOPAZ lidar retrievals to in situ $\mathrm{O}_{3}$ measurements from seven SciAv Mooney and three NASA Alpha Jet flights, respectively, averaged over $1 \mathrm{~km}$ vertical bins. The error bars show the standard deviations of the $1 \mathrm{~km}$ column means. (c, d) Differences between the $1 \mathrm{~km}$ mean TOPAZ and aircraft measurements from (a) and (b) plotted as a function of altitude. The vertical dashed lines show the mean differences. The dashed circle in (d) corresponds to the dashed oval in Fig. 13b (see text).

reach $3 \mathrm{~km}$. These limited datasets make the comparisons more sensitive to the influence of individual points. For example, the point surrounded by the dashed circle in Fig. 15d includes the measurements from within the dashed oval in Fig. 13b where the lidar retrieval is clearly smoothing out the vertical gradient compared to the aircraft measurements. If this measurement point is excluded, the mean TOPAZAJAX difference decreases to 3.9 \pm 2.6 . In either case, the differences between the TOPAZ lidar retrievals and the in situ surface and aircraft measurements lie within the combined uncertainties of the different measurements and well within the $10 \%$ accuracy standard set by the ECC ozonesonde.

\section{Summary and conclusions}

The lidar, aircraft, and ozonesonde profiles acquired during the 2016 CABOTS field campaign provide an unprecedented look at the vertical distribution of lower tropospheric $\mathrm{O}_{3}$ above California during late spring and summer. The good agreement between the low-elevation TOPAZ measurements and the collocated and regional $(<45 \mathrm{~km})$ surface monitors suggests that the measurements made at the VMA during CABOTS can be considered representative of the central San Joaquin Valley. Comparisons between the NOAA TOPAZ lidar profiles and the surface and aircraft measurements agree 

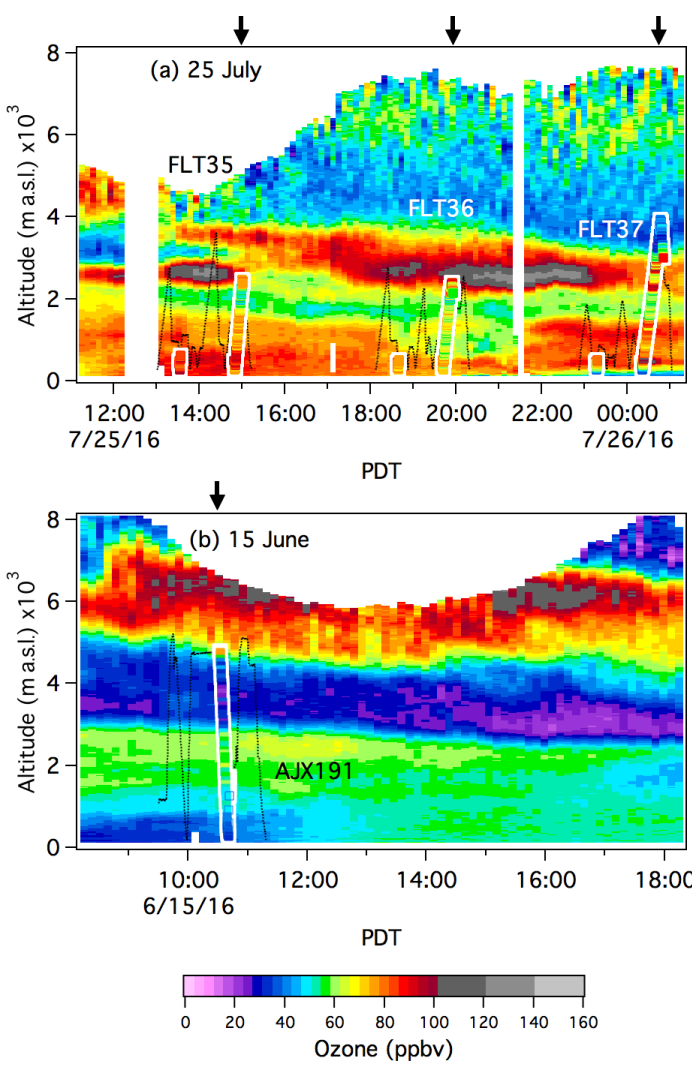

Figure 16. Time-height curtain plots of the TOPAZ ozone measurements from (a) 25 to 26 July with the Scientific Aviation profiles from FLT35, FLT36, and FLT37 superimposed and (b) 15 June with the coincident AJAX profile superimposed. The aircraft measurements made within $5 \mathrm{~km}$ of VMA (arrows) are highlighted by squares and colorized using the same scale as the TOPAZ data. The high $\mathrm{O}_{3}$ layers around $3 \mathrm{~km}$ a.s.l. in (a) are related to the Soberanes Fire; the measurements plotted in the lower right corner of (a) correspond to the data shown in Fig. 10.

within the stated uncertainties, and we conclude that all of these $\mathrm{O}_{3}$ measurements may be used with confidence.

The coordinated lidar and aircraft sampling of $\mathrm{O}_{3}$ above the central San Joaquin Valley during CABOTS also illustrates the synergy between the two types of measurements. Lidar can provide long time series of the $\mathrm{O}_{3}$ (and backscatter) vertical distributions above a fixed location while the aircraft can place the lidar measurements within a larger spatial context and measure other important parameters. This synergy is illustrated by the two time-height curtain plots displayed in Fig. 16. Figure 16a shows the continuous TOPAZ measurements from a $14 \mathrm{~h}$ time span on 25-26 July with the data from SciAv FLT35, FLT36, and FLT37 superimposed. The aircraft measurements made within $5 \mathrm{~km}$ of VMA are highlighted by colored squares outlined in white. Figure $16 \mathrm{~b}$ is similar but shows $10 \mathrm{~h}$ of continuous TOPAZ measurements from 15 June with the AJAX measurements (AJX191) superimposed.
The CABOTS ozonesondes were launched too far away $(>300 \mathrm{~km})$ from the VMA to allow quantitative comparisons with the lidar. However, TOPAZ was relocated to the NASA Jet Propulsion Laboratory (JPL) Table Mountain Facility (TMF) in the San Gabriel Mountains immediately after CABOTS for the Southern California Ozone Observation Project (SCOOP), a multiple lidar and ozonesonde intercomparison organized by the NASA-sponsored Tropospheric Ozone Lidar Network or TOLNet (https://www-air.larc.nasa. gov/missions/TOLNet/, last access: 18 March 2019) at the NASA JPL TMF (Leblanc et al., 2018). The results from the SCOOP intercomparison and those presented here complete the inter-validation of the CABOTS lidar, aircraft, and ozonesonde profile measurements.

Data availability. CARB provided surface monitoring data (available at: https://www.arb.ca.gov/aqmis2/aqdselect.php, CARB, 2019). NOAA provided TOPAZ ozone lidar data (available at: https://www.esrl.noaa.gov/csd/groups/csd3/measurements/cabots/ topaz.php, NOAA, 2019). NASA provided the AJAX aircraft data (available at: https://www.esrl.noaa.gov/csd/groups/csd3/ measurements/cabots/ajax.php, NASA, 2019). UC Davis provided the Scientific Aviation aircraft data (available at: https://www.esrl. noaa.gov/csd/groups/csd3/measurements/cabots/ucdavis/Aircraft/, UC Davis, 2019).

Competing interests. The authors declare that they have no conflict of interest.

Acknowledgements. The California Baseline Ozone Transport Study (CABOTS) field measurements described here were funded by the California Air Resources Board (CARB) under contract nos. 15RD012 (NOAA ESRL), 14-308 (UC Davis), and 17RD004 (NASA Ames). We would like to thank Jin Xu and Eileen McCauley of CARB for their support and assistance in the planning and execution of the project and are grateful to the CARB and the San Joaquin Valley Unified Air Pollution Control District (SJVAPCD) personnel who provided logistical support during the execution of the field campaign. We would also like to thank Cathy BurgdorfRasco of NOAA ESRL and CIRES for maintaining the CABOTS data site. The NOAA team would also like to thank Ann Weickmann, Scott Sandberg, and Richard Marchbanks for their assistance during the field campaign. The NOAA-ESRL lidar operations were also supported by the NOAA Climate Program Office, Atmospheric Chemistry, Carbon Cycle, and Climate (AC4) Program and the NASA-sponsored Tropospheric Ozone Lidar Network (TOLNet, http://www-air.larc.nasa.gov/missions/TOLNet/, last access: 18 March 2019). The UC Davis-Scientific Aviation measurements were also supported by the U.S. Environmental Protection Agency and Bay Area Air Quality Management District through contract no. 2016-129. Ian C. Faloona was also supported by the California Agricultural Experiment Station, hatch project CA-DLAW-2229-H. The NASA AJAX project was also supported with Ames Research Center director's funds, and the support and partnership of H211, LLC is gratefully acknowledged. Josette E. Mar- 
rero and Ju-Mee Ryoo were supported through the NASA Postdoctoral Program, and Mimi E. McNamara was funded through the Center for Applied Atmospheric Research and Education (NASA MUREP). The views, opinions, and findings contained in this report are those of the author(s) and should not be construed as an official National Oceanic and Atmospheric Administration or U.S. Government position, policy, or decision.

Review statement. This paper was edited by Folkert Boersma and reviewed by two anonymous referees.

\section{References}

Alvarez, R. J., II, Senff, C. J., Langford, A. O., Weickmann, A. M., Law, D. C., Machol, J. L., Merritt, D. A., Marchbanks, R. D., Sandberg, S. P., Brewer, W. A., Hardesty, R. M., and Banta, R. M.: Development and Application of a Compact, Tunable, Solid-State Airborne Ozone Lidar System for Boundary Layer Profiling, J. Atmos. Ocean Tech., 28, 1258-1272, https://doi.org/10.1175/Jtech-D-10-05044.1, 2011.

Ancellet, G. and Ravetta, F.: Analysis and validation of ozone variability observed by lidar during the ESCOMPTE-2001 campaign, Atmos. Res., 74, 435-459, https://doi.org/10.1016/j.atmosres.2004.10.003, 2005.

Asher, E. C., Christensen, J. N., Post, A., Perry, K., Cliff, S. S., Zhao, Y. J., Trousdell, J., and Faloona, I.: The Transport of Asian Dust and Combustion Aerosols and Associated Ozone to North America as Observed From a Mountaintop Monitoring Site in the California Coast Range, J. Geophys. Res.-Atmos., 123, 56675680, https://doi.org/10.1029/2017jd028075, 2018.

Avnery, S., Mauzerall, D. L., Liu, J. F., and Horowitz, L. W.: Global crop yield reductions due to surface ozone exposure: 2. Year 2030 potential crop production losses and economic damage under two scenarios of O-3 pollution, Atmos. Environ., 45, 22972309, https://doi.org/10.1016/j.atmosenv.2011.01.002, 2011a.

Avnery, S., Mauzerall, D. L., Liu, J. F., and Horowitz, L. W.: Global crop yield reductions due to surface ozone exposure: 1. Year 2000 crop production losses and economic damage, Atmos. Environ., 45, 2284-2296, https://doi.org/10.1016/j.atmosenv.2010.11.045, $2011 \mathrm{~b}$.

Bao, J. W., Michelson, S. A., Persson, P. O. G., Djalalova, I. V., and Wilczak, J. M.: Observed and WRF-simulated lowlevel winds in a high-ozone episode during the Central California Ozone Study, J. Appl. Meteorol. Clim., 47, 2372-2394, https://doi.org/10.1175/2008jamc1822.1, 2008.

Beekmann, M., Ancellet, G., Martin, D., Abonnel, C., Duveerneuil, G., Eideliman, F., Bessemoulin, P., Fritz, N., and Gizard, E.: Intercomparison of tropospheric ozone profiles obtained by electrochemical sondes, a ground based lidar and an airborne UVphotometer, Atmos. Environ., 29, 1027-1042, 1995.

Brune, W. H., Baier, B. C., Thomas, J., Ren, X., Cohen, R. C., Pusede, S. E., Browne, E. C., Goldstein, A. H., Gentner, D. R., Keutsch, F. N., Thornton, J. A., Harrold, S., Lopez-Hilfiker, F. D., and Wennberg, P. O.: Ozone production chemistry in the presence of urban plumes, Faraday Discuss., 189, 169-189, https://doi.org/10.1039/c5fd00204d, 2016.
CARB: Surface monitoring data, available at: https://www.arb.ca. gov/aqmis2/aqdselect.php, last access: 18 March 2019.

Hamill, P., Iraci, L. T., Yates, E. L., Gore, W., Bui, T. P., Tanaka, T., and Loewenstein, M.: A New Instrumented Airborne Platform for Atmospheric Research, B. Am. Meteorol. Soc., 97, 397-404, https://doi.org/10.1175/Bams-D-14-00241.1, 2016.

Jaffe, D. A., Cooper, O. R., Fiore, A. M., Henderson, B. H., Tonneson, G. S., Russell, A. G., Henze, D. K., Langford, A. O., Lin, M., and Moore, T.: Scientific assessment of background ozone over the U.S.: Implications for air quality management, Elem. Sci. Anth., 6, 56, https://doi.org/10.1525/elementa.309, 2018.

Johnson, B. J., Oltmans, S. J., Vomel, H., Smit, H. G. J., Deshler, T., and Kroger, C.: Electrochemical concentration cell (ECC) ozonesonde pump efficiency measurements and tests on the sensitivity to ozone of buffered and unbuffered ECC sensor cathode solutions, J. Geophys. Res., 107, 4393, https://doi.org/10.1029/2001jd000557, 2002.

Kempfer, U., Carnuth, W., Lotz, R., and Trickl, T.: A Wide-Range Ultraviolet Lidar System for Tropospheric Ozone Measurements - Development and Application, Rev. Sci. Instrum., 65, 31453164, https://doi.org/10.1063/1.1144769, 1994.

Kovalev, V. A. and McElroy, J. L.: Differential Absorption Lidar Measurement of Vertical Ozone Profiles in the Troposphere That Contains Aerosol Layers with Strong Backscattering Gradients - a Simplified Version, Appl. Optics, 33, 8393-8401, https://doi.org/10.1364/Ao.33.008393, 1994.

Lagarias, J. S. and Sylte, W. W.: Designing and Managing the San Joaquin Valley Air-Quality Study, J. Air Waste Manage. Assoc., 41, 1176-1179, https://doi.org/10.1080/10473289.1991.10466912, 1991.

Langford, A. O., Senff, C. J., Alvarez, R. J., Banta, R. M., and Hardesty, R. M.: Long-range transport of ozone from the Los Angeles Basin: A case study, Geophys. Res. Lett., 37, L06807, https://doi.org/10.1029/2010gl042507, 2010.

Langford, A. O., Senff, C. J., Alvarez, R. J., Banta, R. M., Hardesty, R. M., Parrish, D. D., and Ryerson, T. B.: Comparison between the TOPAZ Airborne Ozone Lidar and In Situ Measurements during TexAQS 2006, J. Atmos. Ocean. Tech., 28, 1243-1257, https://doi.org/10.1175/Jtech-D-10-05043.1, 2011.

Langford, A. O., Brioude, J., Cooper, O. R., Senff, C. J., Alvarez, R. J., Hardesty, R. M., Johnson, B. J., and Oltmans, S. J.: Stratospheric influence on surface ozone in the Los Angeles area during late spring and early summer of 2010, J. Geophys. Res., 117, D00V06, https://doi.org/10.1029/2011JD016766, 2012.

Langford, A. O., Senff, C. J., Alvarez, R. J., Brioude, J., Cooper, O. R., Holloway, J. S., Lin, M. Y., Marchbanks, R. D., Pierce, R. B., Sandberg, S. P., Weickmann, A. M., and Williams, E. J.: An overview of the 2013 Las Vegas Ozone Study (LVOS): Impact of stratospheric intrusions and long-range transport on surface air quality, Atmos. Environ., 109, 305-322, https://doi.org/10.1016/J.Atmosenv.2014.08.040, 2015.

Leblanc, T., Brewer, M. A., Wang, P. S., Granados-Muñoz, M. J., Strawbridge, K. B., Travis, M., Firanski, B., Sullivan, J. T., McGee, T. J., Sumnicht, G. K., Twigg, L. W., Berkoff, T. A., Carrion, W., Gronoff, G., Aknan, A., Chen, G., Alvarez, R. J., Langford, A. O., Senff, C. J., Kirgis, G., Johnson, M. S., Kuang, S., and Newchurch, M. J.: Validation of the TOLNet lidars: the Southern California Ozone Observation Project (SCOOP), At- 
mos. Meas. Tech., 11, 6137-6162, https://doi.org/10.5194/amt11-6137-2018, 2018.

Lin, M. Y., Fiore, A. M., Cooper, O. R., Horowitz, L. W., Langford, A. O., Levy, H., Johnson, B. J., Naik, V., Oltmans, S. J., and Senff, C. J.: Springtime high surface ozone events over the western United States: Quantifying the role of stratospheric intrusions, J. Geophys. Res., 117, D00v22, https://doi.org/10.1029/2012jd018151, 2012a.

Lin, M. Y., Fiore, A. M., Horowitz, L. W., Cooper, O. R., Naik, V., Holloway, J., Johnson, B. J., Middlebrook, A. M., Oltmans, S. J., Pollack, I. B., Ryerson, T. B., Warner, J. X., Wiedinmyer, C., Wilson, J., and Wyman, B.: Transport of Asian ozone pollution into surface air over the western United States in spring, J. Geophys. Res., 117, D00v07, https://doi.org/10.1029/2011JD016961, 2012b.

Malicet, J., Daumont, D., Charbonnier, J., Parisse, C., Chakir, A., and Brion, J.: Ozone UV Spectroscopy, 2. Absorption CrossSections and Temperature-Dependence, J. Atmos. Chem., 21, 263-273, https://doi.org/10.1007/Bf00696758, 1995.

NASA: AJAX aircraft data: available at: https://www.esrl.noaa.gov/ csd/groups/csd3/measurements/cabots/ajax.php, last access: 18 March 2019.

NOAA: TOPAZ ozone lidar data, available at: https://www.esrl. noaa.gov/csd/groups/csd3/measurements/cabots/topaz.php, last access: 18 March 2019.

Panek, J., Saah, D., Esperanza, A., Bytnerowicz, A., Fraczek, W., and Cisneros, R.: Ozone distribution in remote ecologically vulnerable terrain of the southern Sierra Nevada, CA, Environ. Pollut., 182, 343-356, https://doi.org/10.1016/j.envpol.2013.07.028, 2013.

Proffitt, M. H. and Langford, A. O.: Ground-based differential absorption lidar system for day or night measurements of ozone throughout the free troposphere, Appl. Optics, 36, 2568-2585, 1997.

Reynolds, S., Bohnenkamp, C., Kaduwela, A., Katayama, B., Shipp, E., Sweet, J., Tanrikulu, S., and Ziman, S.: Central California Ozone Study: Synthesis of Results, in: Nato Sci Peace Sec B, edited by: Steyn, D. and Rao, S., Dordrecht, 571-574, 2010.

Ryerson, T. B., Andrews, A. E., Angevine, W. M., Bates, T. S., Brock, C. A., Cairns, B., Cohen, R. C., Cooper, O. R., de Gouw, J. A., Fehsenfeld, F. C., Ferrare, R. A., Fischer, M. L., Flagan, R. C., Goldstein, A. H., Hair, J. W., Hardesty, R. M., Hostetler, C. A., Jimenez, J. L., Langford, A. O., McCauley, E., McKeen, S. A., Molina, L. T., Nenes, A., Oltmans, S. J., Parrish, D. D., Pederson, J. R., Pierce, R. B., Prather, K., Quinn, P. K., Seinfeld, J. H., Senff, C. J., Sorooshian, A., Stutz, J., Surratt, J. D., Trainer, M., Volkamer, R., Williams, E. J., and Wofsy, S. C.: The 2010 California Research at the Nexus of Air Quality and Climate Change (CalNex) field study, J. Geophys. Res., 118, 58305866, https://doi.org/10.1002/Jgrd.50331, 2013.

Ryoo, J. M., Johnson, M. S., Iraci, L. T., Yates, E. L., and Gore, W.: Investigating sources of ozone over California using AJAX airborne measurements and models.: Assessing the contribution from longrange transport, Atmos. Environ., 155, 53-67, https://doi.org/10.1016/j.atmosenv.2017.02.008, 2017.

Senff, C. J., Alvarez, R. J., Hardesty, R. M., Banta, R. M., and Langford, A. O.: Airborne lidar measurements of ozone flux downwind of Houston and Dallas, J. Geophys. Res., 115, D20307, https://doi.org/10.1029/2009jd013689, 2010.
Schäfer, K., Fommel, G., Hoffmann, H., Briz, S., Junkermann, W., Emeis, S., Jahn, C., Leipold, S., Sedlmaier, A., Dinev, S., Reishofer, G., Windholz, L., Soulakellis, N., Sifakis, N., and Sarigiannis, D.: Three-dimensional ground-based measurements of urban air quality to evaluate satellite derived interpretations for urban air pollution, Water Air Soil Pollut., 2, 91-102, 2002.

Smit, H. G. J., DeBacker, H., Braathen, G., Claude, H., Davies, J., Deshler, T., Johnson, B., Kyro, E., Kivi, R., Oltmans, S., Sasaki, T., Schmidlin, F., Smit, H., Staehelin, J., Stubi, R., Tarasick, D., Thompson, A., Viatte, P., and Witte, J.: Quality Assurance and Quality Control for Ozonesonde Measurements in GAW, World Meteorological Organization, Report No. 201, available at: https://library.wmo.int/pmb_ged/gaw_201_en. pdf (last access: 19 March 2019), 2014.

St. Clair, J. M., Swanson, A. K., Bailey, S. A., Wolfe, G. M., Marrero, J. E., Iraci, L. T., Hagopian, J. G., and Hanisco, T. F.: A new non-resonant laser-induced fluorescence instrument for the airborne in situ measurement of formaldehyde, Atmos. Meas. Tech., 10, 4833-4844, https://doi.org/10.5194/amt10-4833-2017, 2017.

Tanaka, T., Yates, E., Iraci, L. T., Johnson, M. S., Gore, W., Tadic, J., Loewenstein, M., Kuze, A., Frankenberg, C., Butz, A., and Yoshida, Y.: Two-Year Comparison of Airborne Measurements of $\mathrm{CO}_{2}$ and $\mathrm{CH}_{4}$ With GOSAT at Railroad Valley, Nevada, Geoscience and Remote Sensing, IEEE T. Geosci. Remote, 54, 43674375, https://doi.org/10.1109/Tgrs.2016.2539973, 2016.

Trousdell, J. F., Conley, S. A., Post, A., and Faloona, I. C.: Observing entrainment mixing, photochemical ozone production, and regional methane emissions by aircraft using a simple mixed-layer framework, Atmos. Chem. Phys., 16, 15433-15450, https://doi.org/10.5194/acp-16-15433-2016, 2016.

UC Davis: Scientific Aviation aircraft data, available at: https://www.esrl.noaa.gov/csd/groups/csd3/measurements/ cabots/ucdavis/Aircraft/, last access: 18 March 2019.

U.S. Environmental Protection Agency: Policy Assessment for the Review of the Ozone National Ambient Air Quality Standards, Research Triangle Park, North CarolinaEPA-452/R-14006, 2014.

Völger, P., Bösenberg, J., and Shult, I.: Scattering properties of selected model aerosols calculated at UV-wavelengths: Implications for DIAL measurements of tropospheric ozone, Contributions to Atmospheric Physics, 69, 177-187, 1996.

Wang, L., Newchurch, M. J., Alvarez II, R. J., Berkoff, T. A., Brown, S. S., Carrion, W., De Young, R. J., Johnson, B. J., Ganoe, R., Gronoff, G., Kirgis, G., Kuang, S., Langford, A. O., Leblanc, T., McDuffie, E. E., McGee, T. J., Pliutau, D., Senff, C. J., Sullivan, J. T., Sumnicht, G., Twigg, L. W., and Weinheimer, A. J.: Quantifying TOLNet ozone lidar accuracy during the 2014 DISCOVER-AQ and FRAPPÉ campaigns, Atmos. Meas. Tech., 10, 3865-3876, https://doi.org/10.5194/amt10-3865-2017, 2017.

Yates, E. L., Iraci, L. T., Roby, M. C., Pierce, R. B., Johnson, M. S., Reddy, P. J., Tadic, J. M., Loewenstein, M., and Gore, W.: Airborne observations and modeling of springtime stratosphereto-troposphere transport over California, Atmos. Chem. Phys., 13, 12481-12494, https://doi.org/10.5194/acp-13-12481-2013, 2013. 
Yates, E. L., Iraci, L. T., Austerberry, D., Pierce, R. B., Roby, M. C., Tadic, J. M., Loewenstein, M., and Gore, W.: Characterizing the impacts of vertical transport and photochemical ozone production on an exceedance area, Atmos. Environ., 109, 342-350, https://doi.org/10.1016/j.atmosenv.2014.09.002, 2015.

Zaveri, R. A., Shaw, W. J., Cziczo, D. J., Schmid, B., Ferrare, R. A., Alexander, M. L., Alexandrov, M., Alvarez, R. J., Arnott, W. P., Atkinson, D. B., Baidar, S., Banta, R. M., Barnard, J. C., Beranek, J., Berg, L. K., Brechtel, F., Brewer, W. A., Cahill, J. F., Cairns, B., Cappa, C. D., Chand, D., China, S., Comstock, J. M., Dubey, M. K., Easter, R. C., Erickson, M. H., Fast, J. D., Floerchinger, C., Flowers, B. A., Fortner, E., Gaffney, J. S., Gilles, M. K., Gorkowski, K., Gustafson, W. I., Gyawali, M., Hair, J., Hardesty, R. M., Harworth, J. W., Herndon, S., Hiranuma, N., Hostetler, C., Hubbe, J. M., Jayne, J. T., Jeong, H., Jobson, B. T., Kassianov, E. I., Kleinman, L. I., Kluzek, C., Knighton, B., Kolesar, K. R., Kuang, C., Kubátová, A., Langford, A. O., Laskin, A., Laulainen, N., Marchbanks, R. D., Mazzoleni, C., Mei, F., Moffet, R. C., Nelson, D., Obland, M. D., Oetjen, H., Onasch, T. B., Ortega, I., Ottaviani, M., Pekour, M., Prather, K. A., Radney, J. G., Rogers, R. R., Sandberg, S. P., Sedlacek, A., Senff, C. J., Senum, G., Setyan, A., Shilling, J. E., Shrivastava, M., Song, C., Springston, S. R., Subramanian, R., Suski, K., Tomlinson, J., Volkamer, R., Wallace, H. W., Wang, J., Weickmann, A. M., Worsnop, D. R., Yu, X.-Y., Zelenyuk, A., and Zhang, Q.: Overview of the 2010 Carbonaceous Aerosols and Radiative Effects Study (CARES), Atmos. Chem. Phys., 12, 7647-7687, https://doi.org/10.5194/acp-12-7647-2012, 2012. 